Keywords: Saltstone

Retention: Permanent

\title{
Evaluation of Fabric Membranes for Use in Saltstone Drain Water System
}

\author{
B.R. Pickenheim \\ D.H. Miller \\ P.R. Burket
}

March 2012

Savannah River National Laboratory Savannah River Nuclear Solutions Aiken, SC 29808

Prepared for the U.S. Department of Energy under contract number DE-AC09-08SR22470. 
SRNL-STI-2012-00109

Revision 0

\section{DISCLAIMER}

This work was prepared under an agreement with and funded by the U.S. Government. Neither the U.S. Government or its employees, nor any of its contractors, subcontractors or their employees, makes any express or implied:

1. warranty or assumes any legal liability for the accuracy, completeness, or for the use or results of such use of any information, product, or process disclosed; or

2. representation that such use or results of such use would not infringe privately owned rights; or

3. endorsement or recommendation of any specifically identified commercial product, process, or service.

Any views and opinions of authors expressed in this work do not necessarily state or reflect those of the United States Government, or its contractors, or subcontractors.

\section{Printed in the United States of America \\ Prepared for U.S. Department of Energy}




\section{REVIEWS AND APPROVALS}

AUTHORS:

B.R. Pickenheim, Engineering Process Development

Date

D.H. Miller, Engineering Process Development

Date

P.R. Burket, Engineering Process Development

Date

TECHNICAL REVIEW:

A.D. Cozzi, Engineering Process Development

Date

APPROVAL:

A.B. Barnes, Manager

Date

Engineering Process Development

S.L. Marra, Manager

Date

Environmental \& Chemical Process Technology Research Programs

J.E. Occhipinti, Manager

Date

Waste Solidification Engineering 
SRNL-STI-2012-00109

Revision 0

\section{EXECUTIVE SUMMARY}

Saltstone Disposal Unit 2 contains a sheet drain fabric intended to separate solids from drain water to be returned to the Salt Feed Tank. A similar system installed in Vault 4 appears to be ineffective in keeping solids out of the drain water return lines. Waste Solidification Engineering is considering installation of an additional fabric membrane to supplement the existing sheet drain in SDU 2. Amerdrain 200 is the product currently installed in SDU 2. This product is no longer available, so Sitedrain 94 was used as the replacement product in this testing. Fabrics with apparent opening sizes of 10, 25, 50 and 100 microns were evaluated. These fabrics were evaluated under three separate test conditions, a water flow test, a solids retention test and a grout pour test.

A flow test with water showed that installation of an additional filter layer will predictably reduce the theoretical flux through the sheet drain. The manufacturer reports the flux for Sitedrain 94 as $150 \mathrm{gpm} / \mathrm{ft}^{2}$ by ASTM D-4491. This compares reasonably well with the $117 \mathrm{gpm} / \mathrm{ft}^{2}$ obtained in this testing. A combination of the 10 micron fabric with Sitedrain 94 could be expected to decrease flux by about 10 times as compared to Sitedrain 94 alone.

The different media were used to filter a slag and fly ash mixture from water. Slag historically has the smallest nominal particle size of the premix components. Cement was omitted from the test because of its reactivity with water would prohibit accurately particle size measurements of the filtered samples. All four media sizes were able to remove greater than $95 \%$ of particles larger than 100 microns from the slurry. The smaller opening sizes were increasingly effective in removing more particles. The 10 micron filter captured $15 \%$ of the total amount of solids used in the test. This result implies that some insoluble particles may still be able to enter the drain water collection system, although the overall solids rejection is significantly improved over the current design.

Test boxes were filled with grout to evaluate the performance of the sheet drain and fabrics in a simulated vault environment. All of the tests produced a similar amount of drain water, between $8-11 \%$ of the amount of water in the mix, which is expected with the targeted formulation. All of the collected drain waters contained some amount of solids, although the 10 micron filter did not appear to allow any premix materials to pass through. The solids collected from this box are believed to consist of calcium carbonate based on one ICP-AES measurement.

Any of the four candidate fabrics would be an improvement over the sheet drain alone relative to solids removal. The 10 micron fabric is the only candidate that stopped all premix material from passing. The 10 micron fabric will also cause the largest decrease in flux. This decrease in flux was not enough to inhibit the total amount of drain water removed, but may lead to increased time to remove standing water prior to subsequent pours in the facility. The acceptability of reduced liquid flux through the 10 micron fabric will depend on the amount of excess water to be removed, the time available for water removal and the total area of fabric installed at the disposal cell. 


\section{TABLE OF CONTENTS}

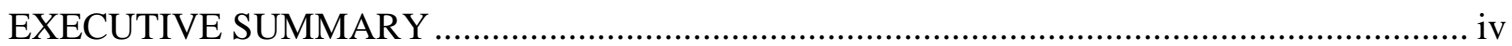

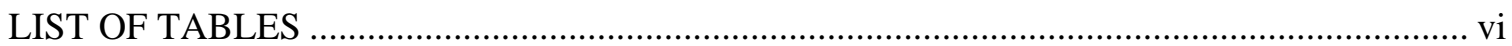

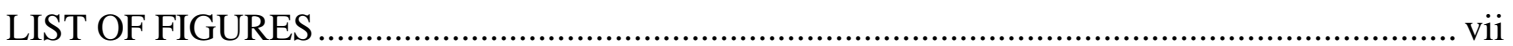

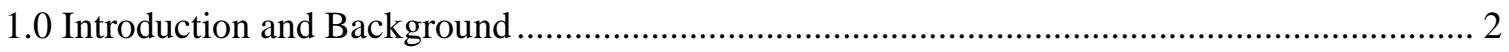

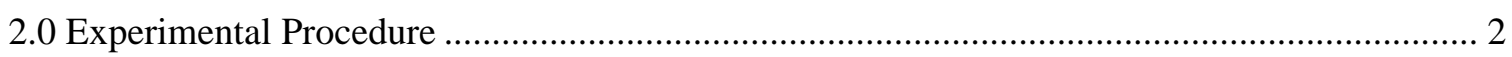

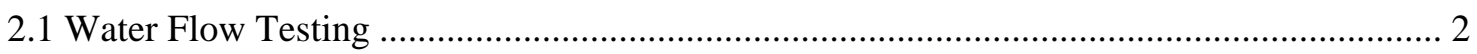

2.2 Solids Retention Testing.................................................................................................... 5

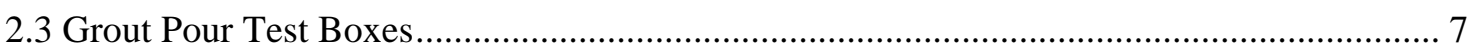

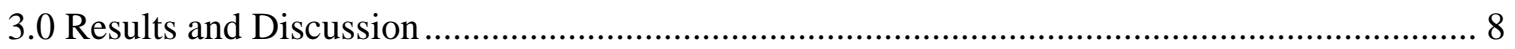

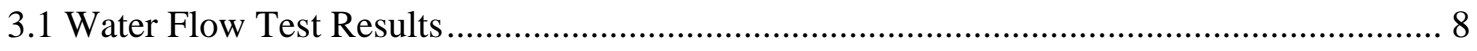

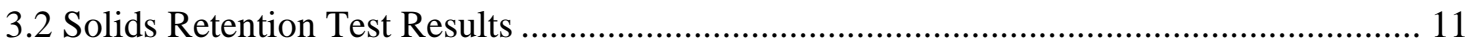

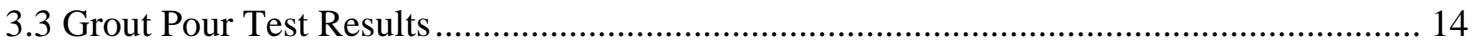

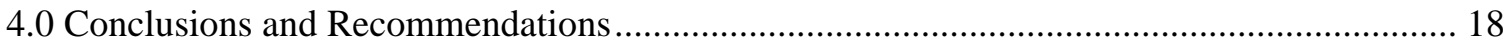

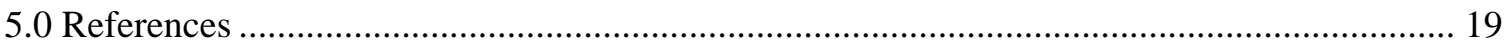

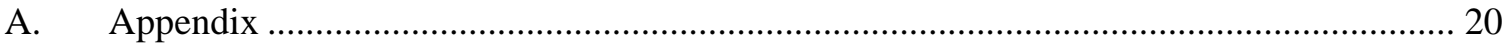




\section{LIST OF TABLES}

Table 1-1. Sheet Drain Physical Properties ................................................................................ 2

Table 2-1. Filter Height and Area Covered by Water (inch or inch ${ }^{2}$ ) ........................................ 5

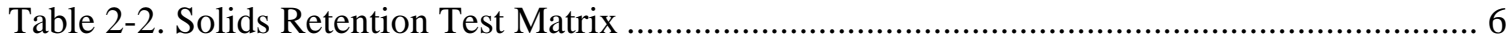

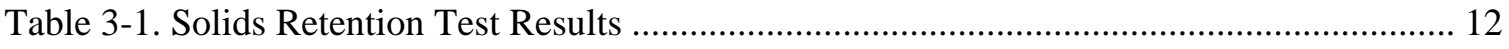

Table 3-2. Solids Retention with Sitedrain 94 Backing Test Results.......................................... 12

Table 3-3. General Particle Size Distribution of Different Test Fabric Solutions......................... 13

Table 3-4. Drain water and Solids Masses Collected ................................................................ 17 


\section{LIST OF FIGURES}

Figure 2-1. Test Rig for Horizontal Flow Testing .................................................................... 3

Figure 2-2. Determination of Area of Filter Covered by Water ..................................................... 4

Figure 2-3. Unassembled Test Unit with 10 micron Fabric ......................................................... 6

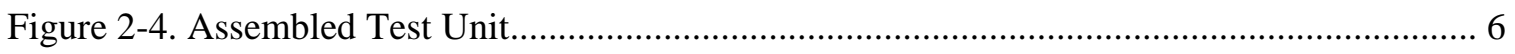

Figure 2-5. Empty Drain water Test Box (Sitedrain 94 w/ 10 micron fabric)................................ 7

Figure 3-1. Water Flux with Fabric Only (Horizontal Test) …................................................ 8

Figure 3-2. Water Flux with Sitedrain 94 and Fabric Together (Horizontal Test) ......................... 9

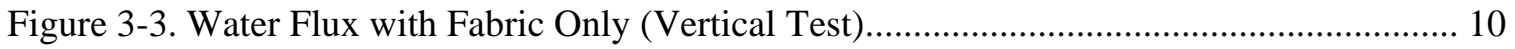

Figure 3-4. Water Flux with Sitedrain 94 and Fabric Together (Vertical Test) ............................ 11

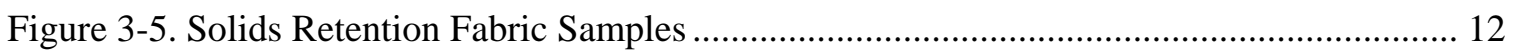

Figure 3-6. Particle Size Distribution (volume) of 50/50 Slag/Fly Ash ....................................... 13

Figure 3-7. Particle Size Distribution (volume) of Solids After 10 micron Filter......................... 14

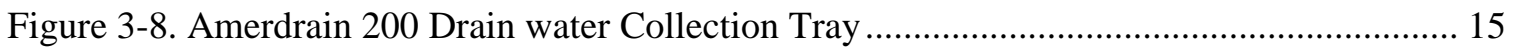

Figure 3-9. 10 Micron Filter Drain water Collection Tray …........................................................ 16

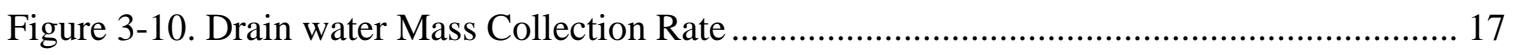

Figure A-1. Particle Size Analysis of 50/50 Slag/Fly Ash ......................................................... 21

Figure A-2. Particle Size Analysis of Solids After 10 Micron Filter .......................................... 22

Figure A-3. Particle Size Analysis of Solids After 25 Micron Filter ......................................... 23

Figure A-4. Particle Size Analysis of Solids After 50 Micron Filter .......................................... 24

Figure A-5. Particle Size Analysis of Solids After 100 Micron Filter ........................................ 25 


\section{LIST OF ABBREVIATIONS}

$\begin{array}{ll}\text { ASTM } & \text { American Society for Testing and Materials } \\ \text { GPM } & \text { Gallons per Minute } \\ \text { ICP-AES } & \text { Inductively Coupled Plasma - Atomic Emission Spectroscopy } \\ \text { RH } & \text { Relative Humidity } \\ \text { SDU } & \text { Saltstone Disposal Unit } \\ \text { SFT } & \text { Salt Feed Tank } \\ \text { SRNL } & \text { Savannah River National Laboratory } \\ \text { TDC } & \text { Top Dead Center } \\ \text { w/p } & \text { Water to Premix Ratio } \\ \text { WSE } & \text { Waste Solidification Engineering } \\ \text { wt \% } & \text { Weight Percent }\end{array}$




\subsection{Introduction and Background}

Saltstone Disposal Unit (SDU) 2 contains a sheet drain fabric intended to separate solids from drain water to be returned to the Salt Feed Tank (SFT). A similar system installed in Vault 4 appears to be ineffective in keeping solids out of the drain water return lines. Waste Solidification Engineering (WSE) is considering installation of an additional fabric membrane to supplement the existing sheet drain in SDU 2. WSE has requested that SRNL evaluate the candidate fabrics to determine feasibility for use in SDU 2. ${ }^{1}$ This scope was performed under the guidance of a Task Technical and Quality Assurance Plan (TT\&QAP). ${ }^{2}$

Amerdrain 200 is the product currently installed in SDU 2. This product is no longer available, so Sitedrain 94 was used as the replacement product in this testing. A mock-up box constructed with Amerdrain 200 was left over from previous testing, so it was used in this study to provide a comparison point between the two materials. Sitedrain 94 is the manufacturer recommended replacement product. Table 1-1 shows the typical physical properties of the two products as reported by the manufacturer.,

Table 1-1. Sheet Drain Physical Properties

\begin{tabular}{|l|c|c|c|c|}
\hline Typical Property Values & $\begin{array}{c}\text { ASTM Test } \\
\text { Method }\end{array}$ & $\begin{array}{c}\text { Unit of } \\
\text { Measure }\end{array}$ & $\begin{array}{c}\text { SITEDRAIN } \\
94\end{array}$ & $\begin{array}{c}\text { AMERDRAIN } \\
200\end{array}$ \\
\hline \hline Fabric \\
\hline \hline Water Flow Rate & D-4491 & gpm/ft ${ }^{2}$ & 150 & 165 \\
\hline Grab Tensile Strength & D-4632 & lbs & 130 & 100 \\
\hline Puncture Resistance & D-4833 & lbs & 75 & 65 \\
\hline Apparent Opening Size & D-4751 & micron & 210 & 210 \\
\hline Grab Elongation & D-4632 & $\%$ & 70 & 65 \\
\hline UV Resistance & D-4355 & $\% / 500$ hrs & 70 & 70 \\
\hline \hline Core & \multicolumn{5}{|l|}{} \\
\hline \hline Thickness & D-1777 & in & 0.25 & 0.25 \\
\hline Compressive Strength & D-1621 & psf & 9000 & 11000 \\
\hline Flow Rate & D-4716 & gpm/ft & 12.5 & 12.5 \\
\hline
\end{tabular}

Fabrics with apparent opening sizes of 10, 25, 50 and 100 microns were evaluated. These fabrics were evaluated under three separate test conditions, a water flow test, a solids retention test and a grout pour test.

\subsection{Experimental Procedure}

\subsection{Water Flow Testing}

A method was developed to measure the water flow characteristics of the various filtering fabrics. The water flow through the individual fabrics was measured and then compared to the results with the candidate fabrics combined with the available sheet drain material. The flow rate was measured under different conditions of constant head pressure. 
The test rig consisted of a nominal 4-inch schedule 40 clear plastic pipe with an elbow and a standard pipe flange. The filter media was sandwiched between the flange gaskets and the assembly was leveled and held in a vice over a sink with the flange and filter media in the horizontal run. Three marks were placed on the horizontal pipe at about the one-quarter, one-half, and three-quarters full levels. A photograph of the apparatus is included as Figure 2-1. Test Rig for Horizontal Flow Testing

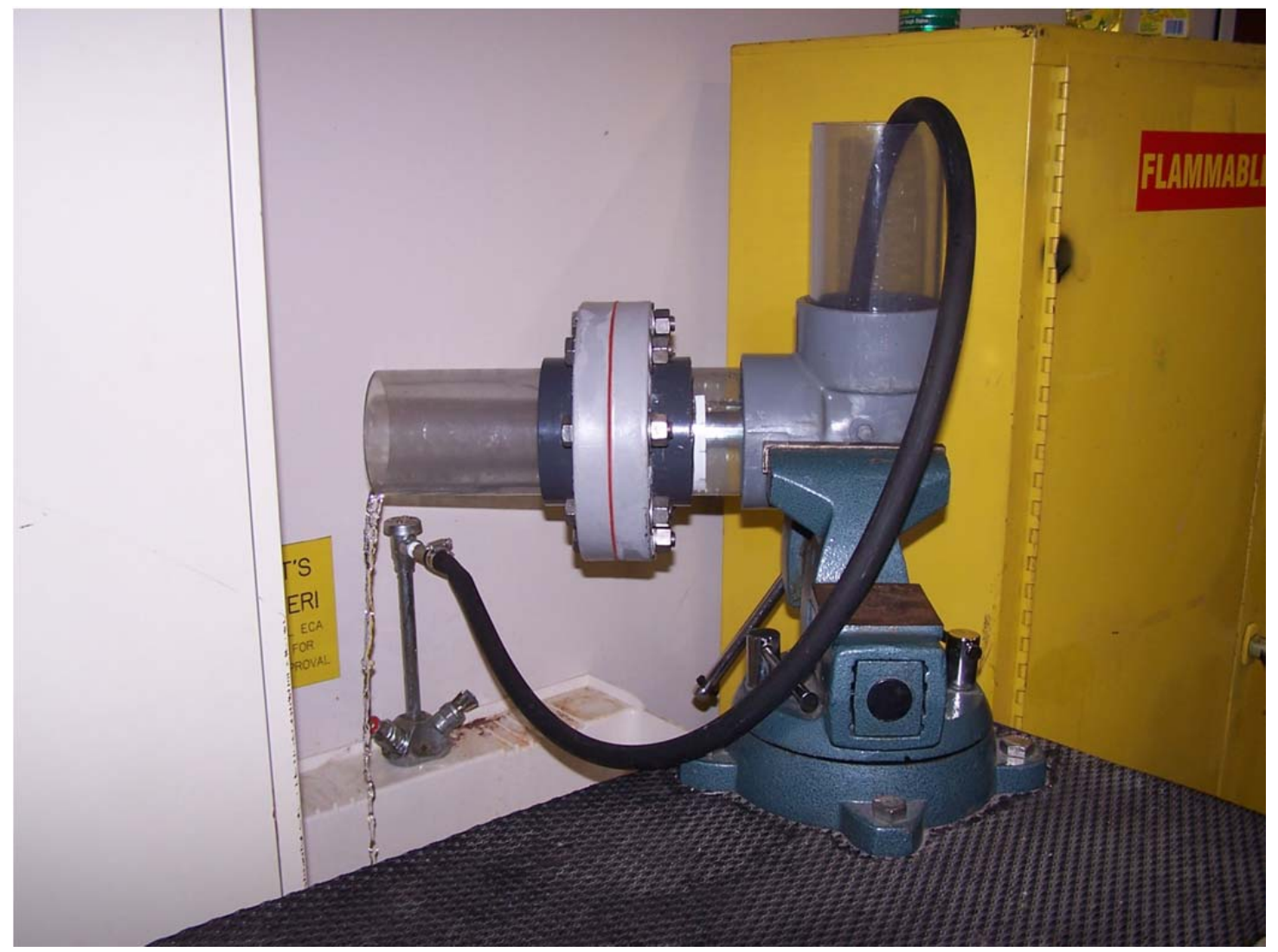

Figure 2-1. Test Rig for Horizontal Flow Testing

Water was introduced into the test rig via a hose. The flow was adjusted until the water level reached the top (three-quarter) mark on the horizontal pipe and remained steady at that level. All water passing through the filter flowed out the end of the horizontal pipe. In all cases, no adjustments were necessary to keep the liquid level at steady state once it was attained. Three replicate measurements of the flow rate were taken by collecting water leaving the pipe into a container for a measured duration, then measuring the mass change of the container for the collected water. Next, the flow rate was lowered until the water level reached the middle (onehalf) mark on the horizontal pipe and remained steady at that level. Three flow measurements were taken, then the same was performed at the bottom (one-quarter) mark on the pipe.

Flow rates were determined with the following media sandwiched in the flange:

- 100 micron filter fabric only

- 50 micron filter fabric only

- 25 micron filter fabric only

- 10 micron filter fabric only 
- 100 micron filter fabric in front of Sitedrain 94 material

- 50 micron filter fabric in front of Sitedrain 94 material

- 25 micron filter fabric in front of Sitedrain 94 material

- 10 micron filter fabric in front of Sitedrain 94 material.

Water flux is the desired reported value for this experiment. The area was determined by measuring the distance from top dead center on the horizontal pipe down to the level mark on the pipe, see Figure 2-2. The segment arc was outer pipe circumference - 2x(TDC-level mark)). The apothem was then determined based on the radius of the outer pipe wall and the segment arc length. The segment area was then determined based on the pipe inner radius and the apothem. For the case where the pipe was three quarters full, the segment area was subtracted from the full pipe area to get the area covered by water. The water height for levels 1 and 2 is reported as the segment height. The water height is reported as the inner diameter minus the segment height for level 3. Values for the segment areas and water height are reported in Table 2-1.

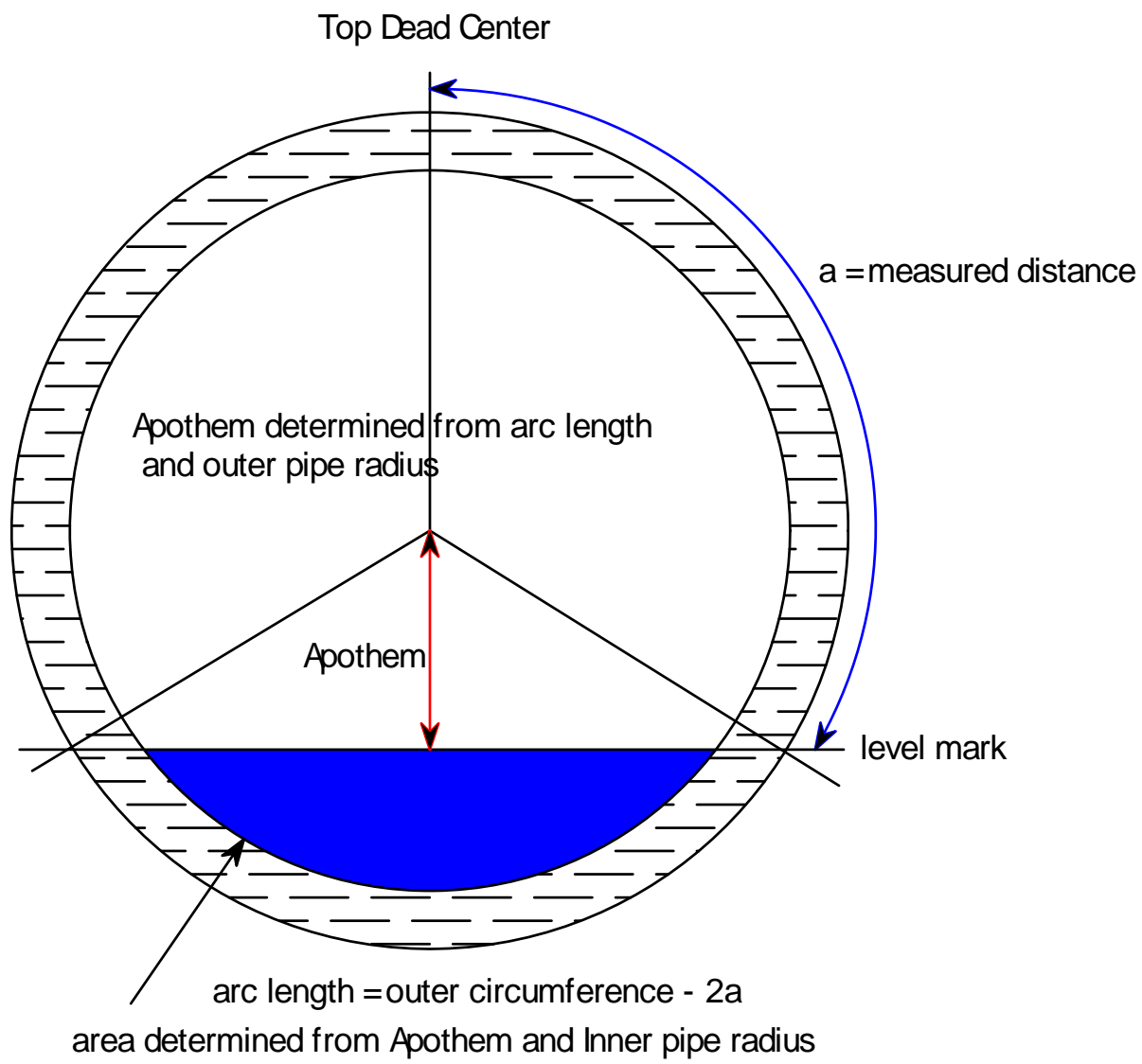

Figure 2-2. Determination of Area of Filter Covered by Water 
SRNL-STI-2012-00109

Revision 0

Table 2-1. Filter Height and Area Covered by Water (inch or inch ${ }^{2}$ )

\begin{tabular}{|c|c|c|c|c|c|c|c|}
\hline & & Segment Arc & Segment Arc & Apothem & Segment Area & Water Height & Full Area \\
\hline tdc & 0 & Full & Empty & & & & \\
\hline level 3, $\mathrm{a}=$ & 2.69 & 8.76 & 5.38 & 0.827 & 2.79 & 2.76 & 9.01 \\
\hline level $2, \quad a=$ & 3.62 & 6.89 & & 0.091 & 5.54 & 1.85 & 5.54 \\
\hline level $1, \mathrm{a}=$ & 4.69 & 4.76 & & 1.10 & 1.86 & 0.83 & 1.86 \\
\hline outer radius & 2.25 & & & & & & \\
\hline inner radius & 1.94 & & & & & & \\
\hline outer circumference & 14.14 & & & & & & \\
\hline total inner pipe area & 11.79 & & & & & & \\
\hline
\end{tabular}

This test allows for comparisons between the different fabrics with the fabric in the same orientation as in the Saltstone vaults. However, because the differential pressure across the fabric is not constant, a standard flux value cannot easily be reported. For this reason, the test was repeated using the same methodology but in a vertical arrangement. The test was again performed at three different water levels (two, three, and four inches), this time providing a constant head pressure across the entire filter.

\subsection{Solids Retention Testing}

In order to evaluate the solids retention properties of the different configurations, a small test unit was assembled. The unit consisted of a clear 2" diameter pipe with a coupling capable of holding a sample of filter media. The pipe was positioned in a vertical position that discharged into a bottle to collect the filtered liquid. The solids chosen for the test were a 50/50 blend of slag and fly ash, which has a particle size distribution that bounds the current premix material used in the facility. Cement was not included in the mixture because its reactivity with water would make it more difficult to accurately measure particle size distribution of the filtered material.

A one gram sample of the dried power was chosen after preliminary testing indicated that this amount of material could be filtered through the fabric without blinding. The one gram sample was mixed in a bottle with $500 \mathrm{ml}$ of water prior to being poured through the filter housing. Another $500 \mathrm{ml}$ of water was then poured over the fabric to insure that all particles were washed through. The fabric was dried at $\sim 105{ }^{\circ} \mathrm{C}$ before being weighed to determine the amount of solids retained. Each test was repeated to obtain an average reading.

The liquid that passed through the fabric was collected and filtered. An Erlenmeyer flask with a Buchner funnel was set up using a 0.45 micron glass filter paper to capture the particles. Less than one percent by volume of the starting material would be expected to pass through a 0.45 micron filter. The glass filter was dried and weighed to determine the quantity of material that had passed through the fabric.

After all the individual fabrics were completed, the tests were repeated with a piece of Sitedrain 94 fabric used in combination with the fabric. The micron rating for the fabrics represents the average pore size opening. The test matrix is shown in Table 2-2: 
Table 2-2. Solids Retention Test Matrix

\begin{tabular}{||c|c|c||}
\hline Test \# & $\begin{array}{c}\text { Fabric } \\
\text { (microns) }\end{array}$ & Backing \\
\hline \hline 1 & 10 & None \\
\hline 2 & 25 & None \\
\hline 3 & 50 & None \\
\hline 4 & 100 & None \\
\hline 5 & 10 & Sitedrain 94 \\
\hline 6 & 25 & Sitedrain 94 \\
\hline 7 & 50 & Sitedrain 94 \\
\hline 8 & 100 & Sitedrain 94 \\
\hline
\end{tabular}

The two inch pipe coupling used for the testing is shown in Figure 2-3 and Figure 2-4.

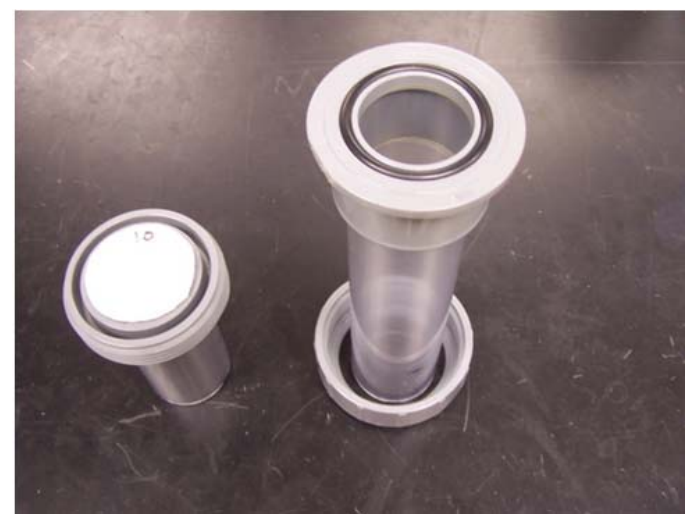

Figure 2-3. Unassembled Test Unit with 10 micron Fabric

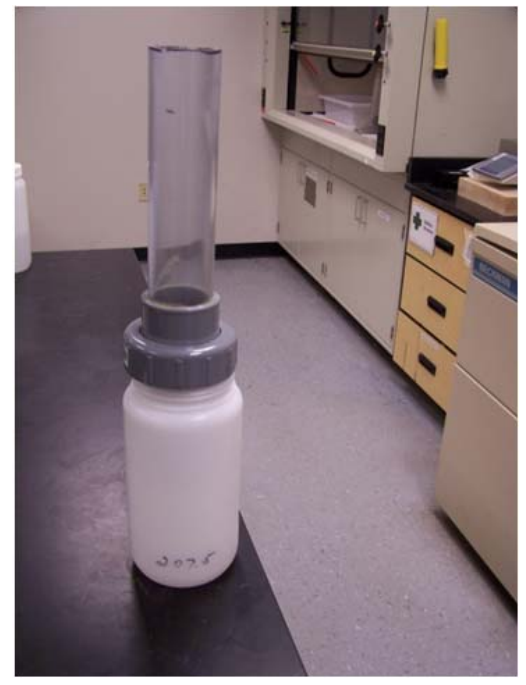

Figure 2-4. Assembled Test Unit 
In addition to measuring the quantity of material retained by the fabric, another objective was to determine the particle sizes that were removed. The test rig was used to process samples without filtering the material that passed through the fabric. The entire liter of water collected was sent for particle size analysis. One gram of the test powder was mixed in one liter of water to serve as a standard.

\subsection{Grout Pour Test Boxes}

Rectangular test boxes were constructed as in previous work ${ }^{5}$ with polycarbonate sides and an open top. The boxes are 1 foot tall by 1 foot wide by 2 feet deep. The sheet drain and fabric material is attached to one of the shorter walls with a slit at the bottom for drain water to drain through. An empty box is shown in Figure 2-5.

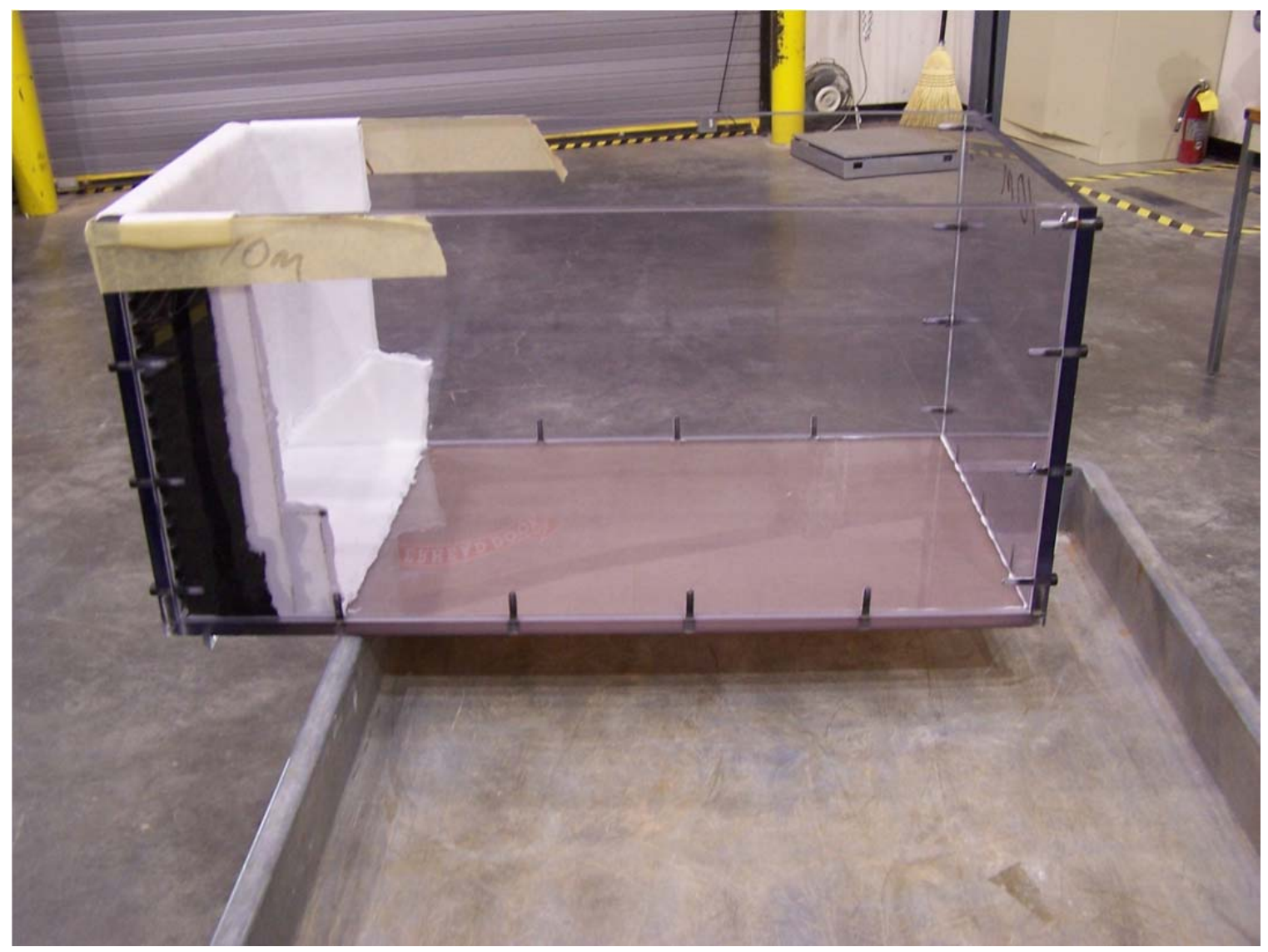

Figure 2-5. Empty Drain water Test Box (Sitedrain 94 w/ 10 micron fabric)

Boxes were constructed with Sitedrain 94 as the base sheet drain material. One test box with each of the four candidate fabrics overlaying the base sheet drain material was built. An additional box was built with a sealed drain water collection reservoir connected to an external tube which allowed for manual draining of the drain water. This box was used to simulate the condition of pouring with the drain void space filled in the facility and allowing the drain water level to equilibrate with the grout level in the vault.

A clean cap formulation was developed to closely mimic the properties of the Saltstone that performed the worst in the 2011 testing. ${ }^{5}$ The target formulation has a gel time greater than two 
hours, a set time of about 48 hours and generate about $10 \%$ bleed by volume. This formulation is not expected to be representative of actual Saltstone operations, but instead provide an excess of bleed and allow more solids to penetrate the sheet drain than would be expected in the facility. The formulation used was 0.66 w/p with 0.05 wt\% (on premix mass) Daratard 17.

The grout was mixed in 5 gallon pails for three minutes after all solids were incorporated. Each box required five pours to fill. The pours were conducted consecutively as quickly as feasible using only one mixer. It takes between 30-40 minutes between the end of the first pour and the end of the fifth pour.

\subsection{Results and Discussion}

\subsection{Water Flow Test Results}

Figure 3-1 and Figure 3-2 show the results of the horizontal flow testing. Results are reported as flux (gallons $/ \mathrm{min} / \mathrm{ft}^{2}$ ) as a function of water column height. Note the head height is not constant across the entire cross section because of the orientation. For this reason, the test was also performed in the vertical orientation.

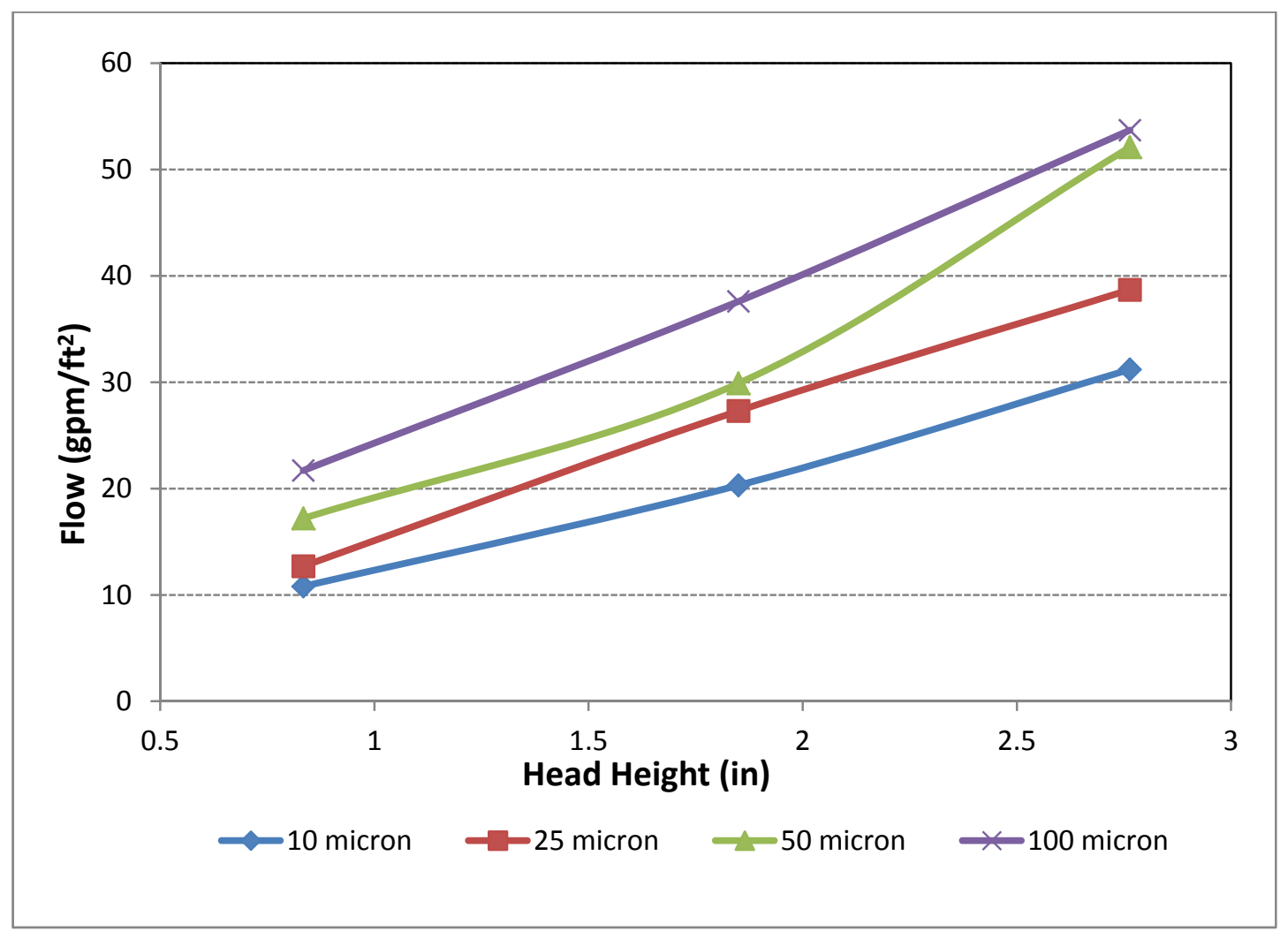

Figure 3-1. Water Flux with Fabric Only (Horizontal Test) 
SRNL-STI-2012-00109

Revision 0

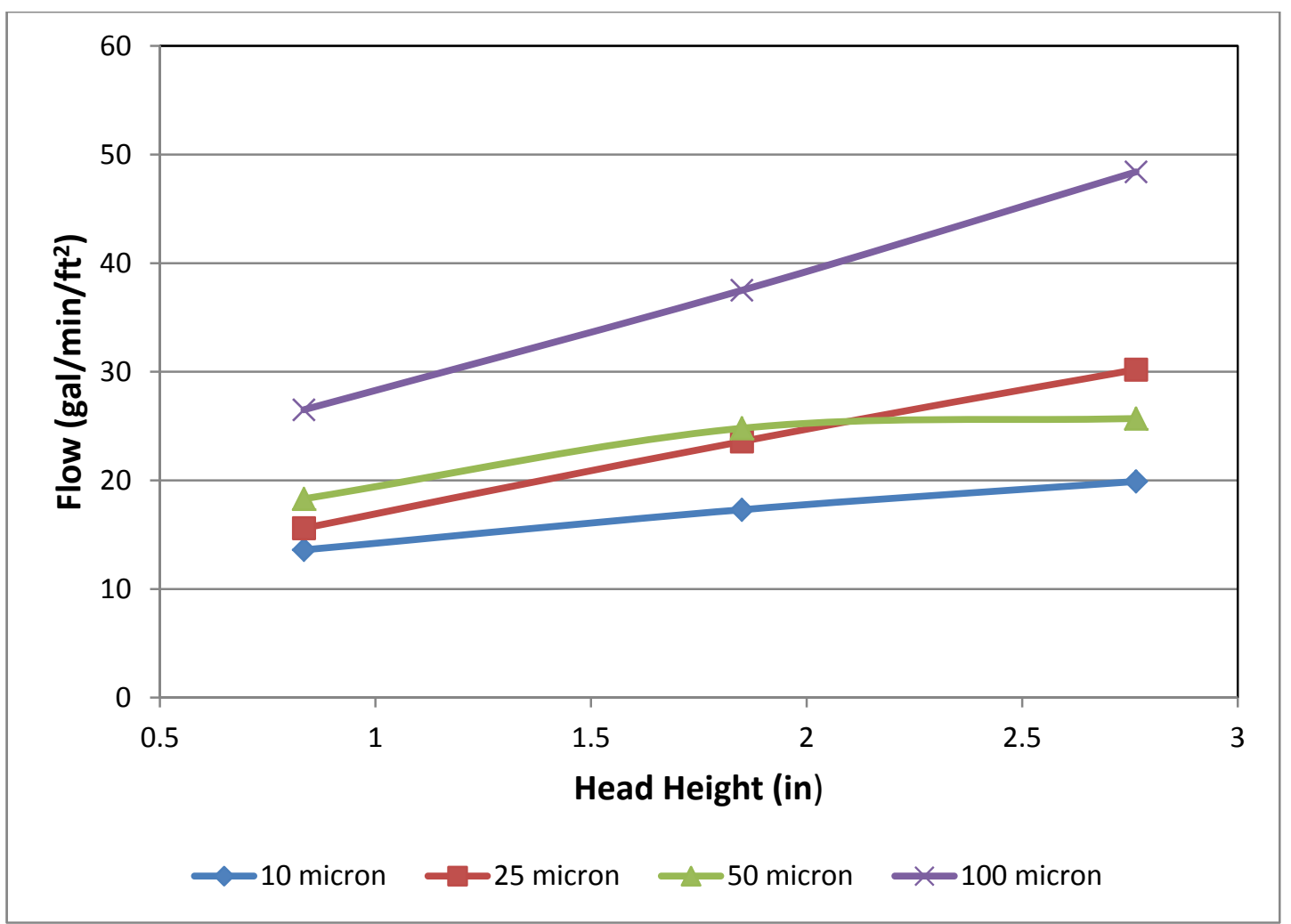

Figure 3-2. Water Flux with Sitedrain 94 and Fabric Together (Horizontal Test)

Figure 3-3 and Figure 3-4 show the results of the vertical water flow testing. Results are reported as flux (gallons $/ \mathrm{min} / \mathrm{ft}^{2}$ ) as a function of water column height. 


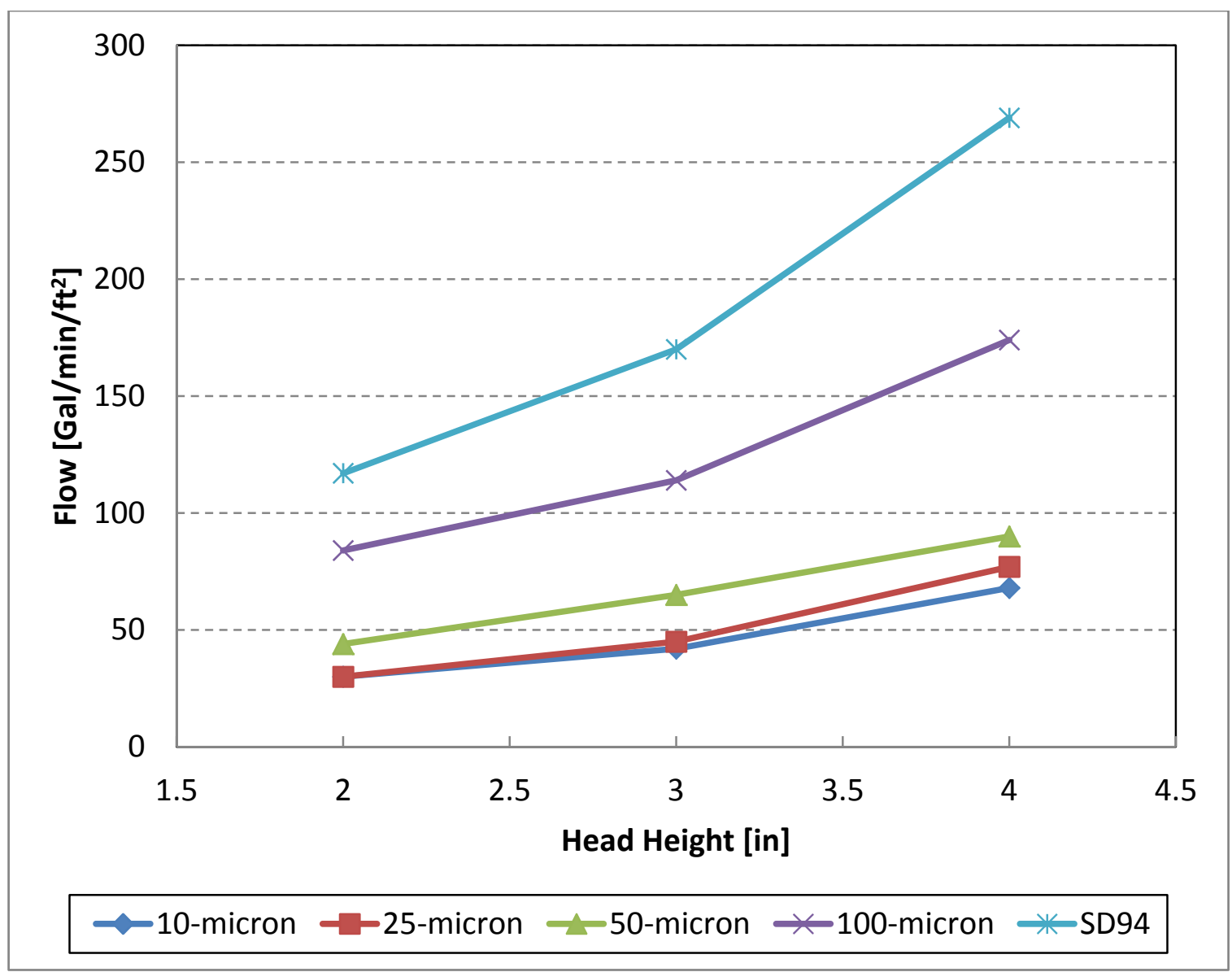

Figure 3-3. Water Flux with Fabric Only (Vertical Test) 


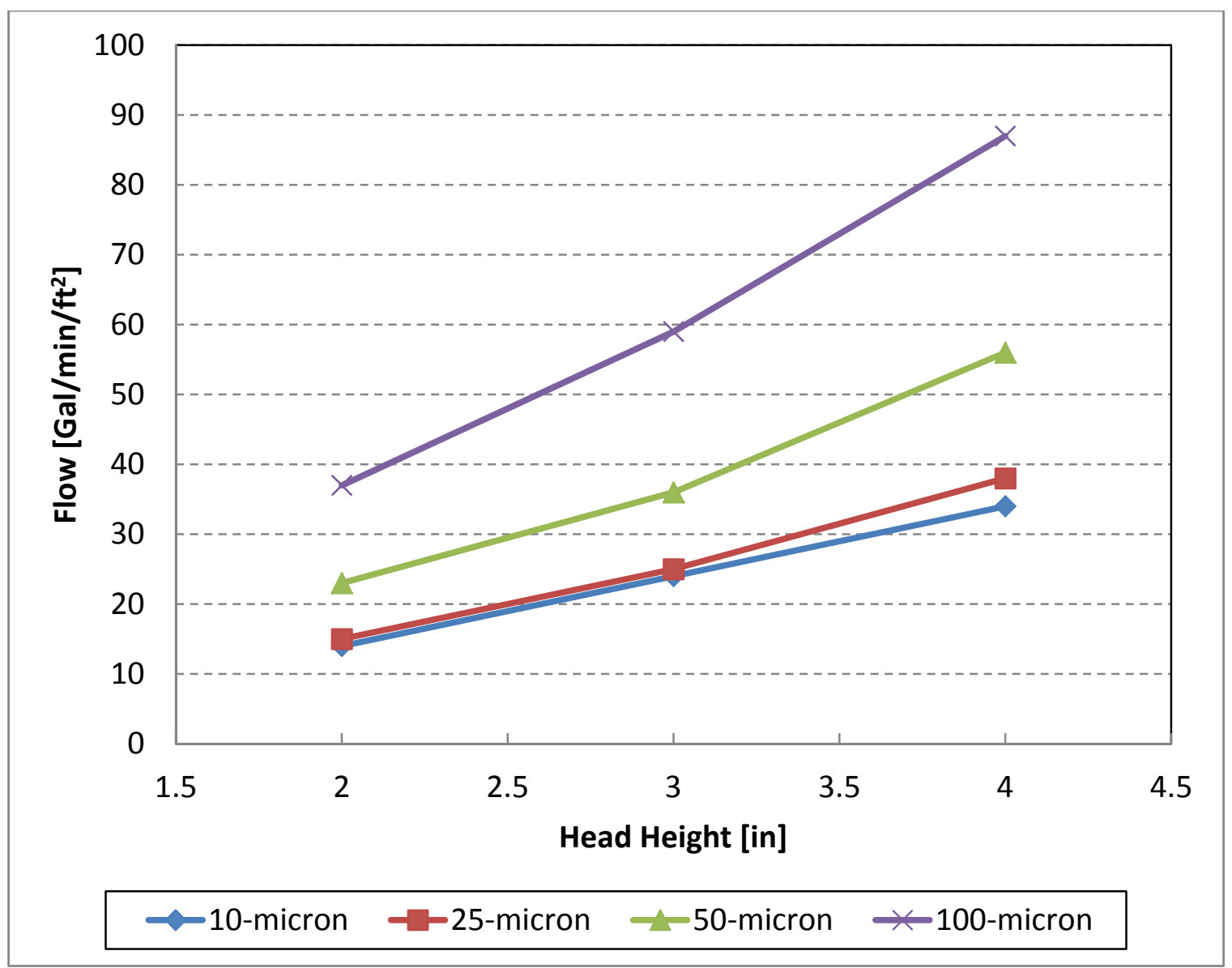

Figure 3-4. Water Flux with Sitedrain 94 and Fabric Together (Vertical Test)

The manufacturer reports the flux for Sitedrain 94 by ASTM D-4491. This compares reasonably well with the result obtained here. As expected, the materials with smaller opening sizes allow lower water flux. Adding multiple layers together further decreases the flux. A combination of the 10 micron fabric with Sitedrain 94 could be expected to allow about $10 \%$ of the flux of Sitedrain 94 alone. Given that Amerdrain 200 has a higher reported flux than the Sitedrain 94, a combination of the 10 micron filter fabric with Amerdrain 200 should be expected to have a higher flux than the combination of 10 micron fabric and Sitedrain 94.

\section{2 $\underline{\text { Solids Retention Test Results }}$}

The results of the retention tests showed that the majority of the slag/fly ash mixture would flow through a section of fabric material that had not been affected by particulate buildup on the surface. As expected, the amount of retention did increase with the lower micron rating as shown in Table 3-1. 
Table 3-1. Solids Retention Test Results

\begin{tabular}{|c|c|c|c||}
\hline $\begin{array}{c}\text { Fabric } \\
\text { Tested } \\
\text { (microns) }\end{array}$ & $\begin{array}{c}\text { Retained on } \\
\text { Fabric } \\
\text { (\%) }\end{array}$ & $\begin{array}{c}\text { Retained on } \\
\mathbf{0 . 4 5} \text { Filter } \\
\text { (\%) }\end{array}$ & $\begin{array}{c}\text { Total } \\
\text { Recovered } \\
(\mathbf{\% )}\end{array}$ \\
\hline \hline 10 & 13.7 & 82.5 & 96.2 \\
\hline 25 & 10.0 & 88.6 & 98.5 \\
\hline 50 & 6.5 & 89.8 & 96.4 \\
\hline 100 & 1.6 & 94.9 & 96.4 \\
\hline
\end{tabular}

During testing it was visually apparent which fabric had retained the most material, as seen in Figure 3-5. The visual indications followed the same trend as shown in the Table 3-1.

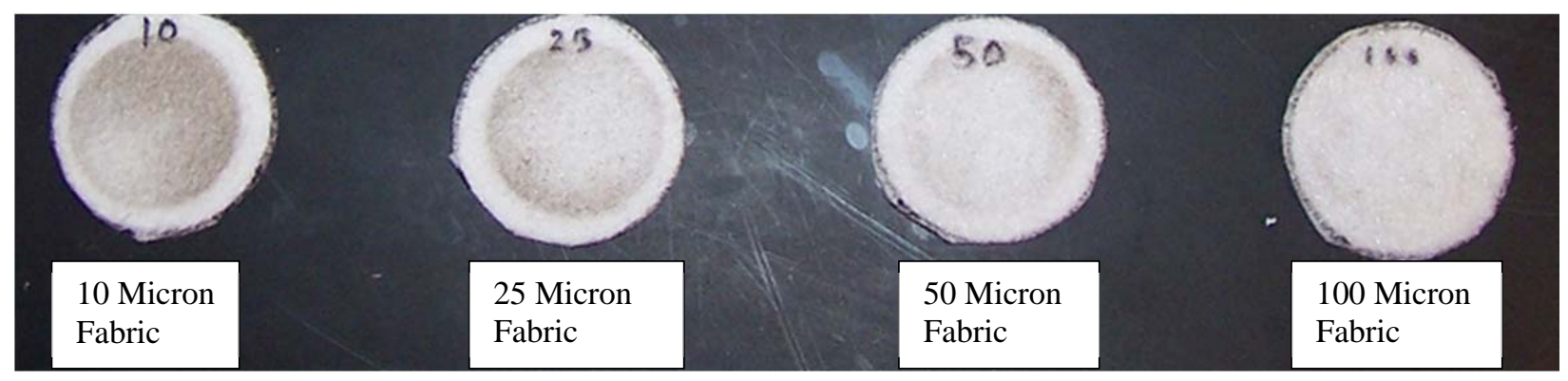

Figure 3-5. Solids Retention Fabric Samples

When the test was repeated using the Sitedrain ${ }^{\circledR} 94$ backing, the results showed a similar trend in the relative efficiency of the fabric and also indicated the ability of the backing to retain a small amount of the material. The results of testing with fabric and backing are shown in Table 3-2.

Table 3-2. Solids Retention with Sitedrain 94 Backing Test Results

\begin{tabular}{|c|c|c|c|c|}
\hline $\begin{array}{c}\text { Fabric } \\
\text { Tested } \\
\text { (microns) }\end{array}$ & $\begin{array}{c}\text { Retained } \\
\text { On Fabric } \\
(\%)\end{array}$ & $\begin{array}{c}\text { Retained on } \\
\text { Backing } \\
(\mathbf{\%})\end{array}$ & $\begin{array}{c}\text { Retained on } \\
\mathbf{0 . 4 5} \text { Filter } \\
(\mathbf{\% )}\end{array}$ & $\begin{array}{c}\text { Total } \\
\text { Recovered } \\
\mathbf{( \% )}\end{array}$ \\
\hline \hline 10 & 15 & 1.9 & 80.3 & 97.3 \\
\hline 25 & 11.9 & 1.6 & 82.5 & 96.1 \\
\hline 50 & 11.7 & 1.9 & 78.7 & 92.3 \\
\hline 100 & 4.2 & 5 & 88.1 & 97.2 \\
\hline
\end{tabular}

The particle size of the material contained in the liquid that passed through the different micron fabrics was measured. While the average particle size of all the solutions remained around 10 microns, the results did show that the different fabrics removed varying amounts of larger particles. Table 3-3 gives a breakdown of the average and ends of the particle size distributions for each of the tested fabrics. Figure 3-6 and Figure 3-7 show the particle size distributions of the starting material and what passed through the 10 micron filter. Complete particle size analysis for all samples is contained in Appendix A. 
Table 3-3. General Particle Size Distribution of Different Test Fabric Solutions

\begin{tabular}{|c|c|c|c|}
\hline $\begin{array}{c}\text { Fabric } \\
\text { Opening } \\
\text { (microns) } \\
\end{array}$ & $\begin{array}{c}10 \% \text { Cumulative } \\
\text { Less Than } \\
\text { (microns) }\end{array}$ & $\begin{array}{c}50 \% \text { Cumulative } \\
\text { Less Than } \\
\text { (microns) }\end{array}$ & $\begin{array}{c}95 \% \text { Cumulative } \\
\text { Less Than } \\
\text { (microns) } \\
\end{array}$ \\
\hline 10 & 1.5 & 9.1 & 33.8 \\
\hline 25 & 1.7 & 10.1 & 45.6 \\
\hline 50 & 1.7 & 10.4 & 49.6 \\
\hline 100 & 1.7 & 10.6 & 64.3 \\
\hline $\begin{array}{l}\text { Standard } \\
\text { Mixture }\end{array}$ & 1.8 & 11.8 & 127 \\
\hline
\end{tabular}

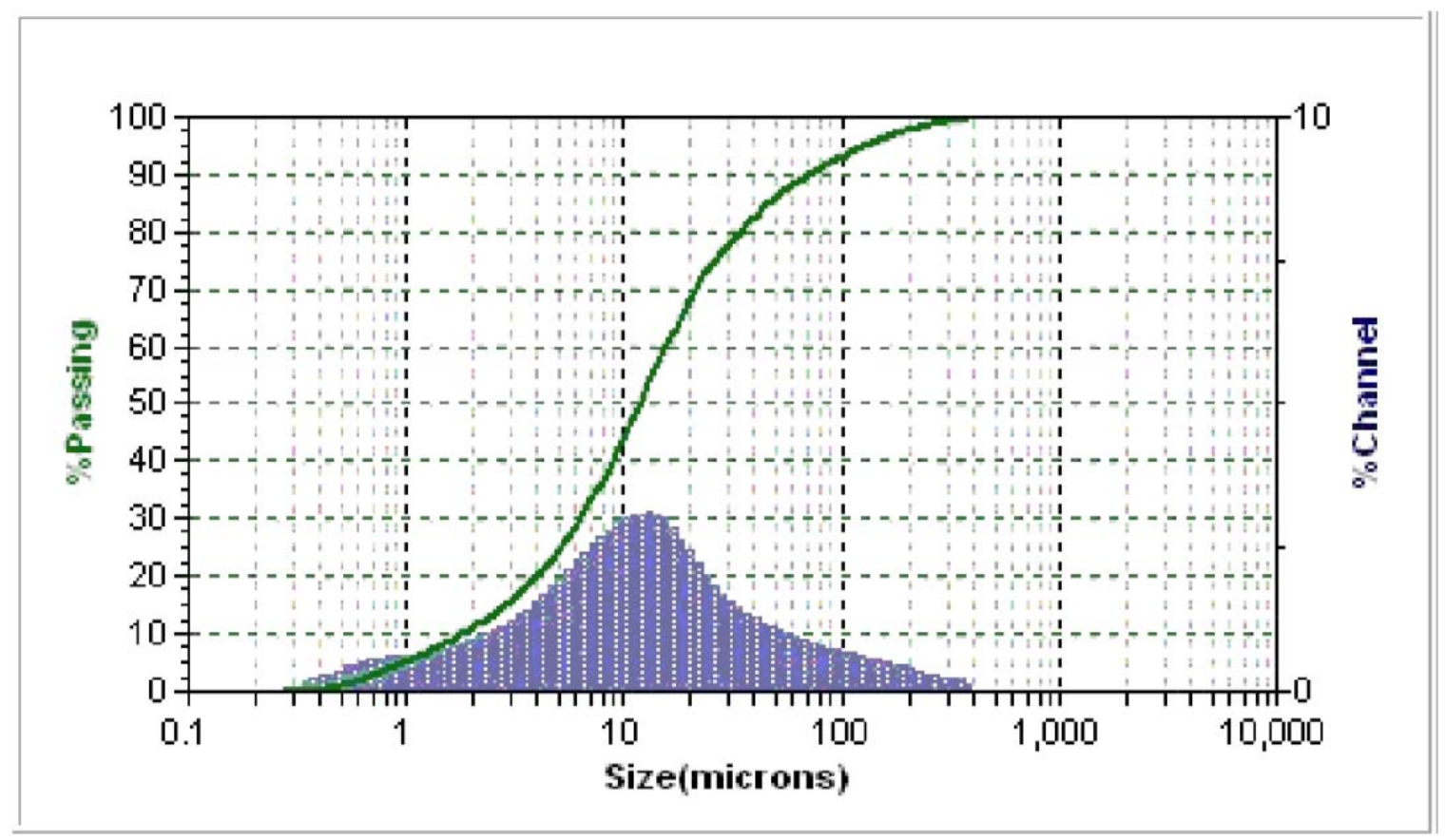

Figure 3-6. Particle Size Distribution (volume) of 50/50 Slag/Fly Ash 


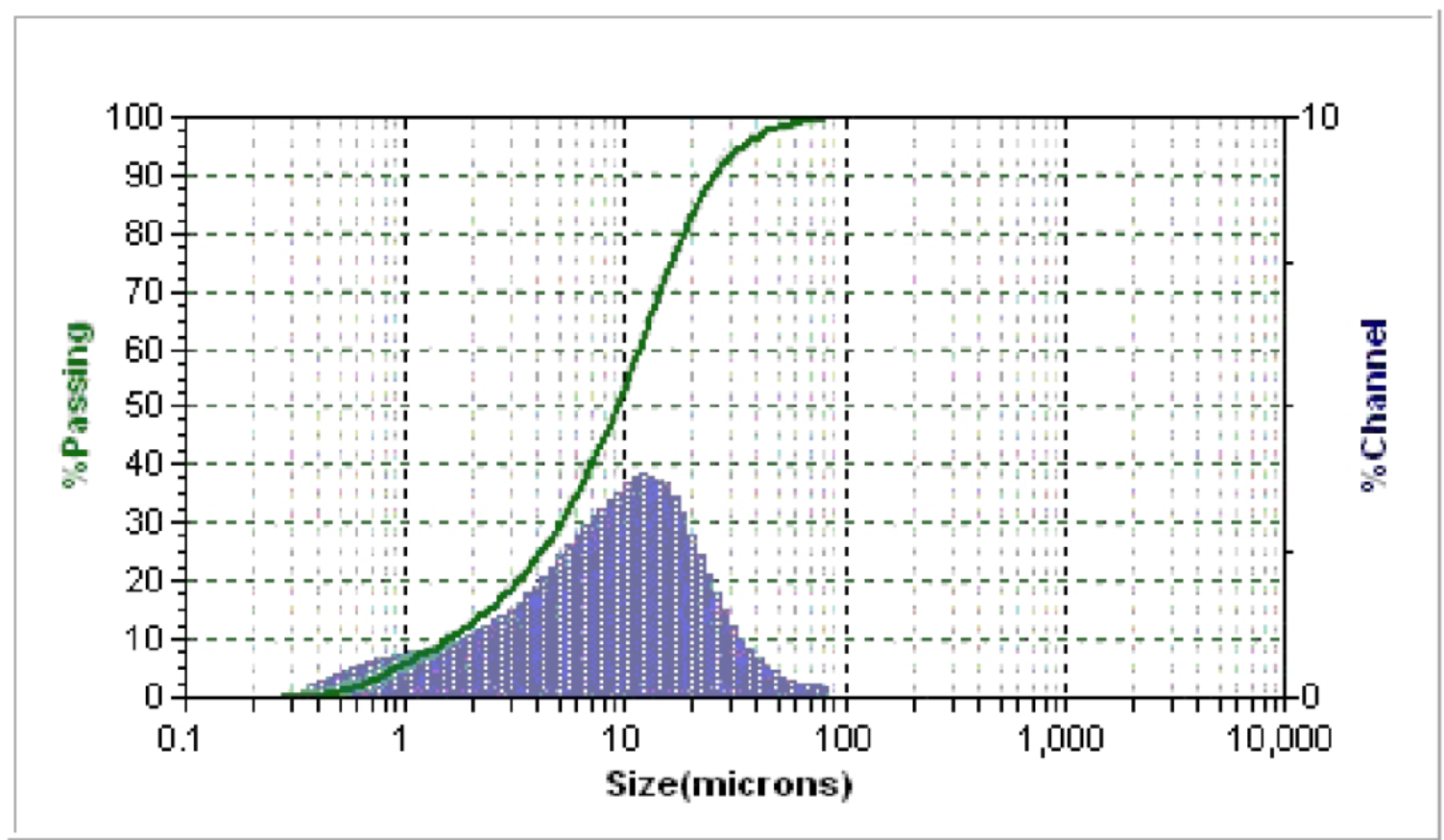

Figure 3-7. Particle Size Distribution (volume) of Solids After 10 micron Filter

\subsection{Grout Pour Test Results}

Total mass of drain water collected was monitored over time as the boxes were being poured. After all drain water was collected, the solids were isolated from the liquid and a total dried mass was obtained. Figure 3-8 and Figure 3-9 show the leachate collection trays from the box tests for Amerdrain 200 only and Sitedrain 94 with the 10 micron filter, respectively, for solids rejection comparison purposes. 


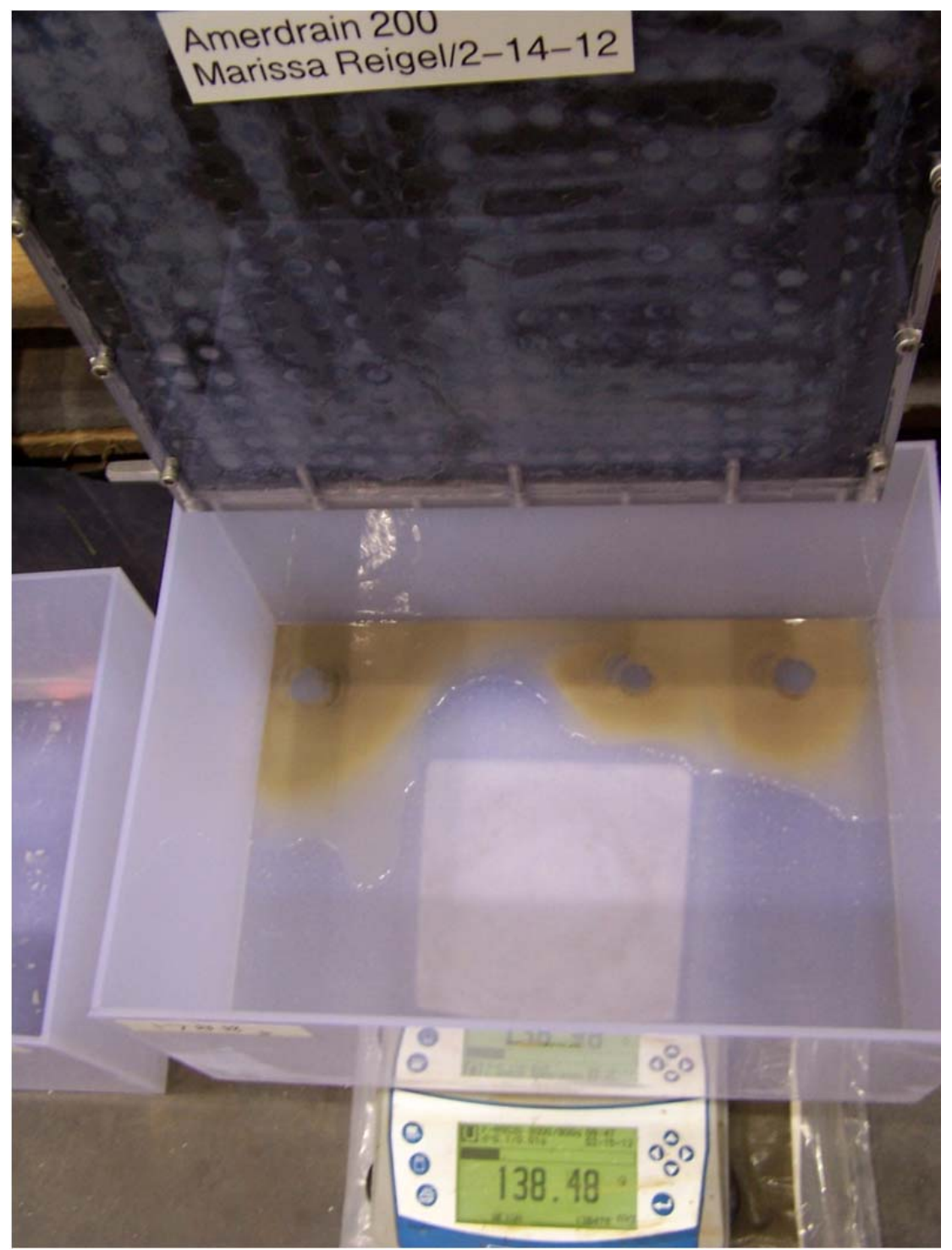

Figure 3-8. Amerdrain 200 Drain water Collection Tray 


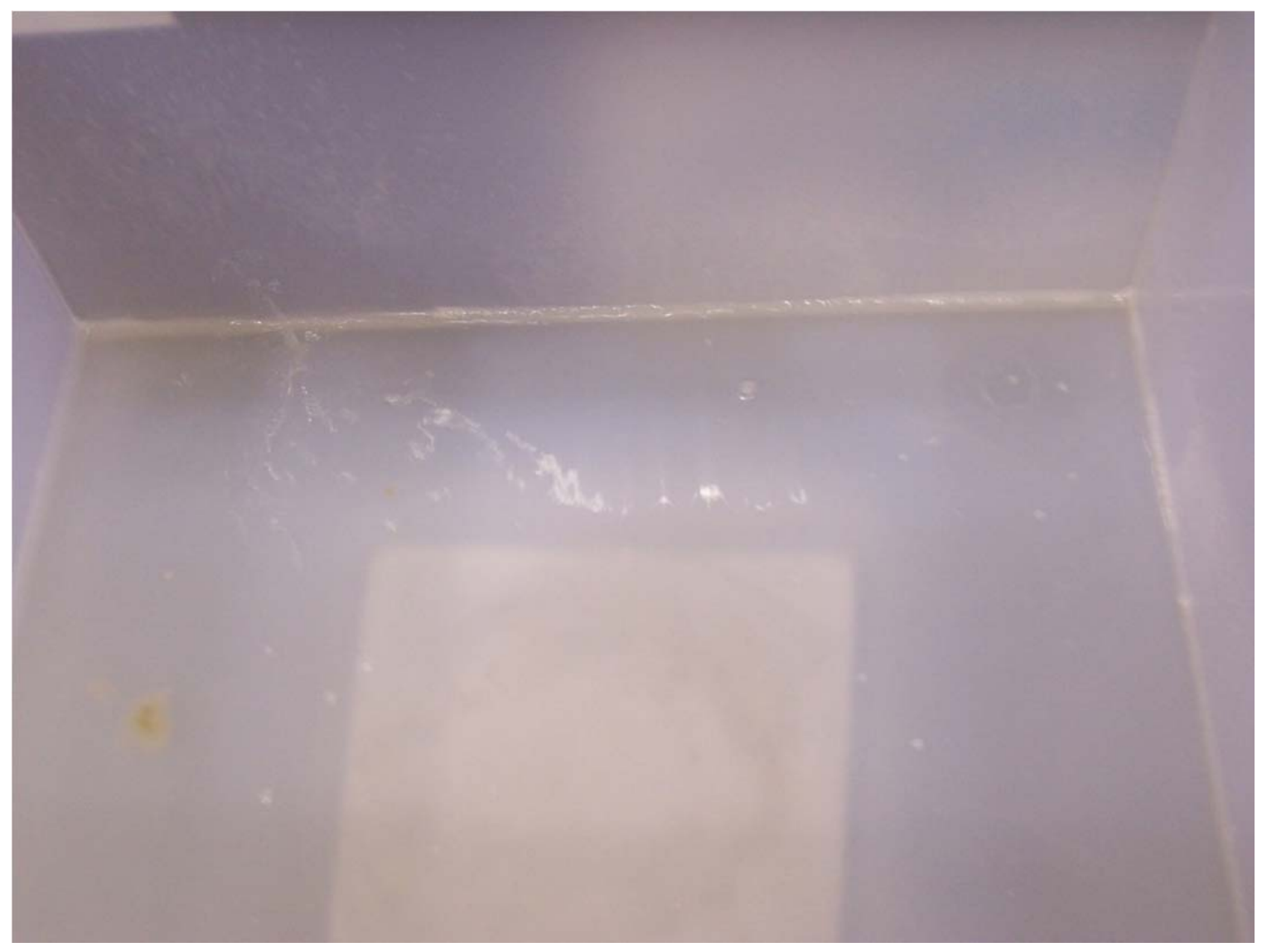

Figure 3-9. 10 Micron Filter Drain water Collection Tray

The Amerdrain 200 box (Figure 3-8) clearly shows collected cementitious solids early in the experiment. The 10 micron box tray (Figure 3-9) shows clear to slightly cloudy liquid with no obvious cementitious materials. The small brown spot on the central left part of the tray was a drip from a bucket as it was poured, not cementitious material that had passed through the sheet drain. The other collection trays showed varying amounts of brownish solids, indicating that cementitious material had passed through the sheet drain. Only the 10 micron filter appeared to prevent all cementitious material from passing through.

Figure 3-10 shows the total mass (drain water and solids) collected as a function of time over the first four hours. In this graph, time $t=0$ is when the first of the five pours was completed. 


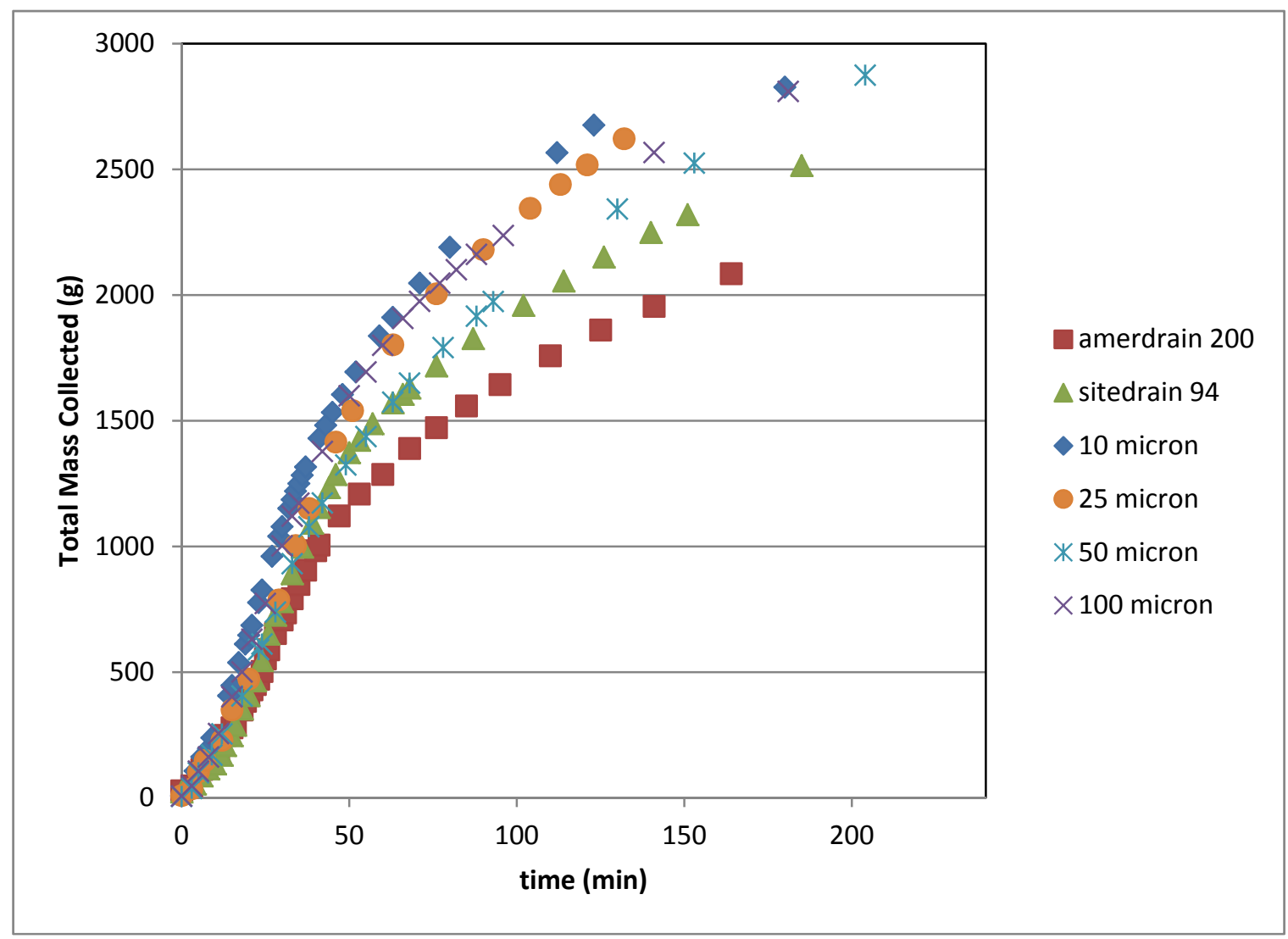

Figure 3-10. Drain water Mass Collection Rate

The total mass collected from each box ranged between 2900 and 4000 grams by the time all drips had stopped (time $>720$ minutes). Note that the boxes as well as the drain water collection reservoirs were uncovered and the temperature and relative humidity (RH) were not controlled during curing. Some amount of evaporation occurred which cannot be quantified. Each box contained 35,970 grams of water and 54,500 grams of premix on a formula basis. The difference between the amount of drain water collected in each box compared to the total mass of grout is within expected experimental error. Every 1000 grams of water represents about $0.02 \mathrm{in} \mathrm{w} / \mathrm{p}$ space, that is, the difference between 3000 grams of drain water collected and 4000 grams of drain water collected would change the w/p of the final grout product by 0.02 .

Table 3-4 shows the total mass collected during each box test.

Table 3-4. Drain water and Solids Masses Collected

\begin{tabular}{|c|c|c|}
\hline Test & $\begin{array}{c}\text { Total Mass } \\
\text { Collected (g) }\end{array}$ & $\begin{array}{c}\text { Mass of Dried } \\
\text { Solids (g) }\end{array}$ \\
\hline \hline Amerdrain 200 & 2956 & 21.3 \\
\hline Sitedrain 94 & 2805 & 10.6 \\
\hline 10 micron & 3338 & 1.12 \\
\hline 25 micron & 3762 & 5.79 \\
\hline 50 micron & 3826 & 6.67 \\
\hline 100 micron & 3034 & 6.90 \\
\hline
\end{tabular}


Any supplemental fabric membrane provides a performance increase relative to either sheet drain fabric alone. The small amount of solids collected from the 10 micron box appeared as a hazy film on top of the liquid in the collection tray. When isolated, these solids were white and flaky. They dissolved readily in aqua regia but not water. They did not appear to be cementitious in nature. The solids were analyzed by Inductively Coupled Plasma Atomic Emission Spectroscopy (ICP-AES). Results indicate the material is mostly calcium carbonate. It cannot be determined at this time whether the solids precipitated in the collection tray or passed through the sheet drain membrane. The film on top of the collection tray liquid was seen in all of the boxes. Only the solids from the 10 micron box were analyzed.

An additional test box was poured where the void space between the wall and the sheet drain was not drained during pouring. A sealed drain water collection tray was attached to the drain area of the box and completely filled with water prior to pouring. Therefore, only the amount of drain water needed to fill the void was allowed to pass through the sheet drain material. This configuration allowed cementitious solids to pass through the sheet drain and into the void space. Approximately five hours after completion of pouring, the void space was completely drained and then refilled. The action of refilling the void space washed additional cementitious solids from the sheet drain and into the collection tray.

\subsection{Conclusions and Recommendations}

Testing was performed to evaluate the feasibility of using supplemental fabric membranes to aid in solids filtration in SDU 2. A flow test with water showed that installation of an additional filter layer will predictably reduce the theoretical flux through the sheet drain. Installation of the 10 micron fabric on top of the sheet drain, for example, may be expected to reduce the flux by a factor of 10 .

$10,25,50$, and 100 micron filter fabrics were used to filter a slag and fly ash mixture from water. All four media sizes were able to remove greater than 95\% of particles larger than 100 microns from the slurry. The smaller opening sizes were increasingly effective in removing more particles. The 10 micron filter captured $15 \%$ of the total amount of solids used in the test.

Test boxes were filled with grout to evaluate the performance of the sheet drain and fabrics in a simulated vault environment. All of the tests produced a similar amount of drain water, between $8-11 \%$ of the amount of water in the mix, which is expected based on the targeted formulation. All of the collected drain waters contained some amount of solids. Only the 10 micron filter did not appear to allow any premix materials to pass through the sheet drain and fabric material. The solids collected from this box are believed to consist of calcium carbonate based on one ICP-AES measurement.

Operating with the void space between the sheet drain and the vault wall filled does not appear to provide any benefit regarding solids retention based on this test. The amount of drain water it takes to fill the void space is sufficient to carry cementitious solids through the sheet drain.

The simulant used in the grout pour tests is not expected to be representative of actual Saltstone grout. The composition was chosen because it was expected to allow large amounts of particle carryover with unrealistically high bleed in an attempt to better distinguish small differences between the different fabrics. Even under these conditions, it is difficult to claim any significant difference between the 25, 50 and 100 micron fabrics. 
The 10 micron fabric is the only candidate that stopped all premix material from passing. The 10 micron fabric will also cause the largest decrease in flux. This decrease in flux was not enough to inhibit the total amount of drain water removed, but may lead to increased time to remove standing water prior to subsequent pours in the facility.

Performing grout pour testing with a simulant that better represents actual Saltstone grout and a representative pour rate may provide further detail that would be useful to managing the process in the facility. However, this testing as performed is sufficient to state that any of the four candidate fabrics will represent a likely increase in performance relative to solids removal.

\subsection{References}

${ }^{1}$ Staub, A.V. Evaluation of Fabric Membrane for Use in Saltstone Drain Water System, HLW-SSF-TTR2012-0010 Rev. 0, Savannah River Site, 2012.

${ }^{2}$ Miller, D.H. Task Technical and Quality Assurance Plan for Fabric Membrane Evaluation for Use in the Saltstone Drain Water System, SRNL-RP-2012-00068 Rev. 0, Savannah River National Laboratory, 2012.

${ }^{3}$ American Wick Drain, SITEDRAIN Sheet 90 Series, americanwick.com, March 6, 2012.

${ }^{4}$ American Wick Drian, AMERDRAIN 200/220, americanwick.com, March 6, 2012.

${ }^{5}$ Reigel, M.M and Clark, E.A, Evaluation of Saltstone Sheet Drain Properties, SRNL-L3100-2011-00156 Rev. 0, Savannah River National Laboratory, 2011. 
SRNL-STI-2012-00109

Revision 0

A. Appendix 

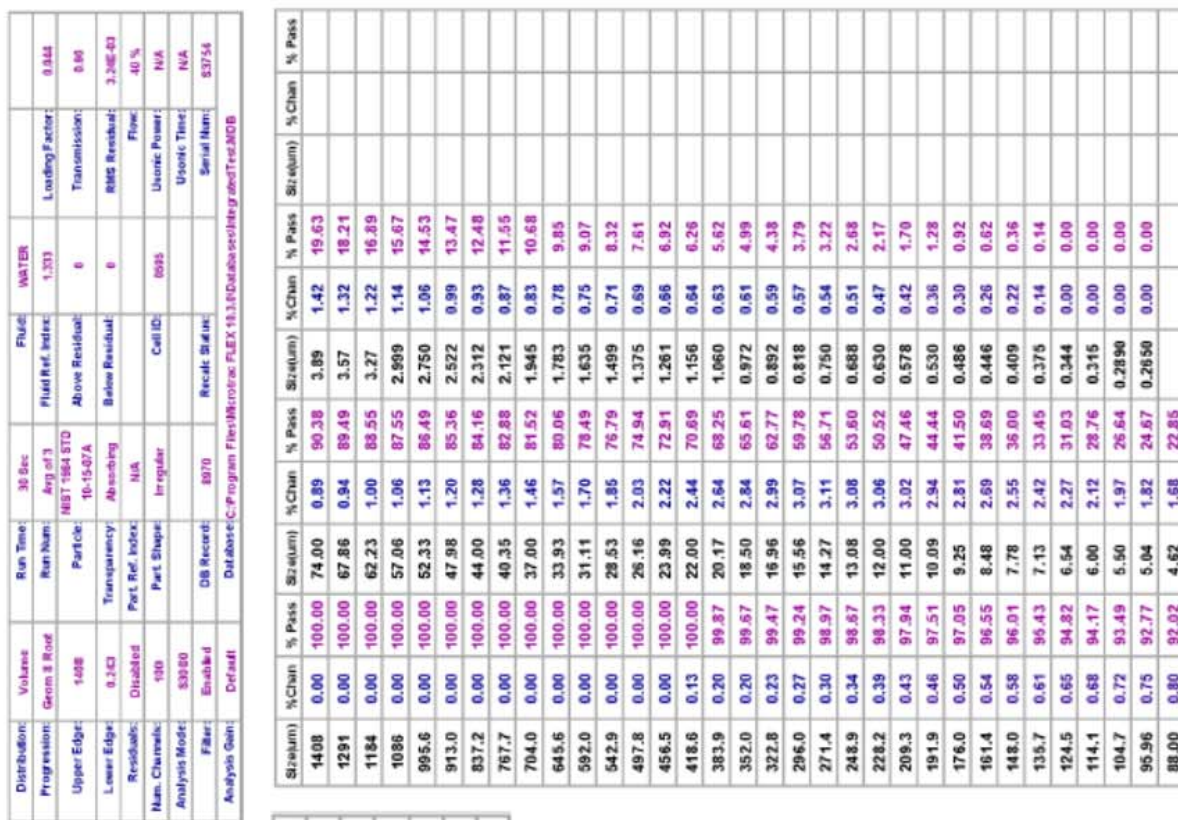

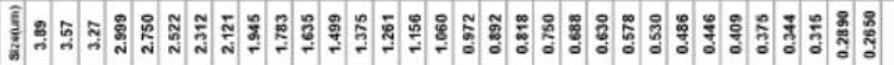

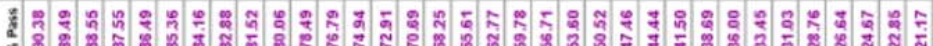

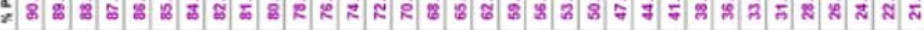

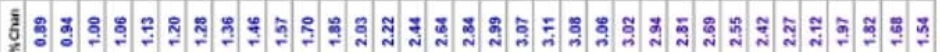

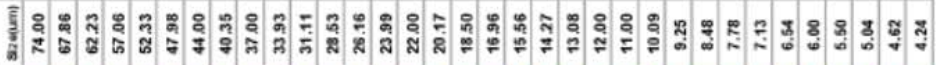
苦:

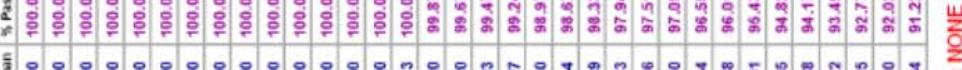
ํํㅀ :

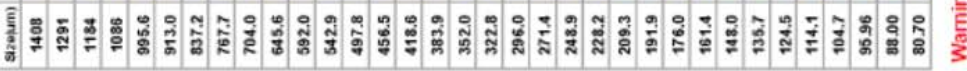
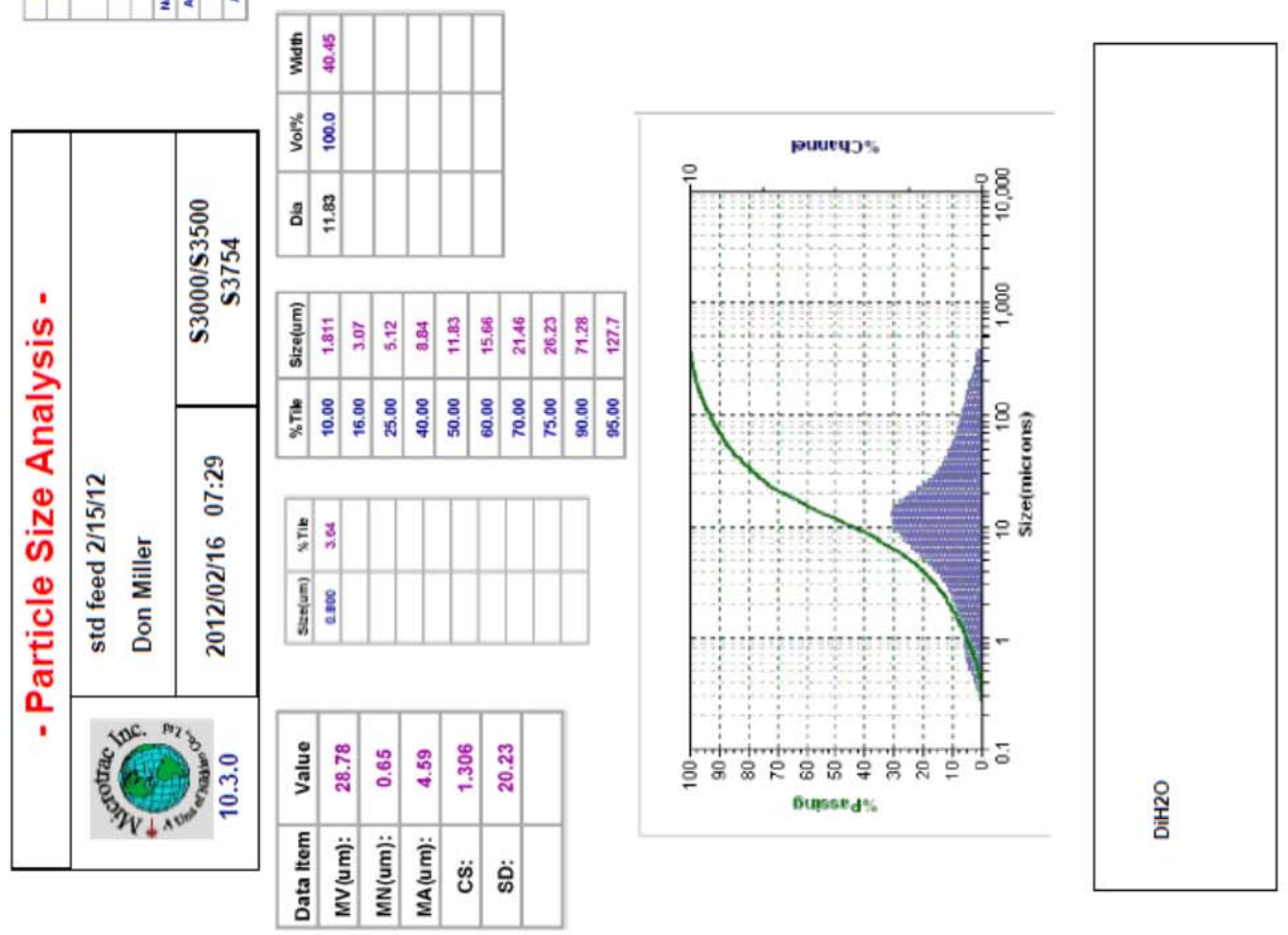

Figure A-1. Particle Size Analysis of 50/50 Slag/Fly Ash 


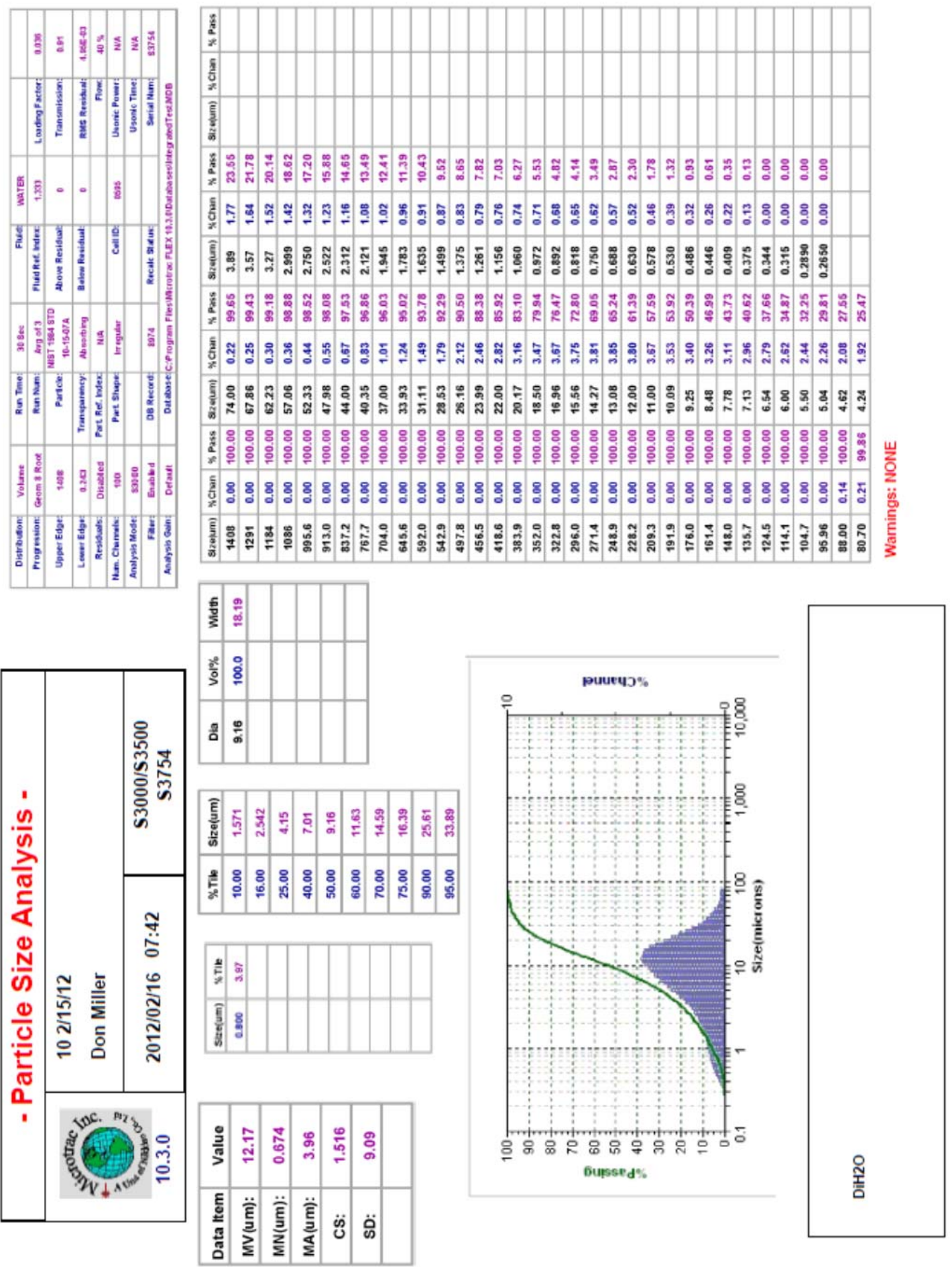

Figure A-2. Particle Size Analysis of Solids After 10 Micron Filter 

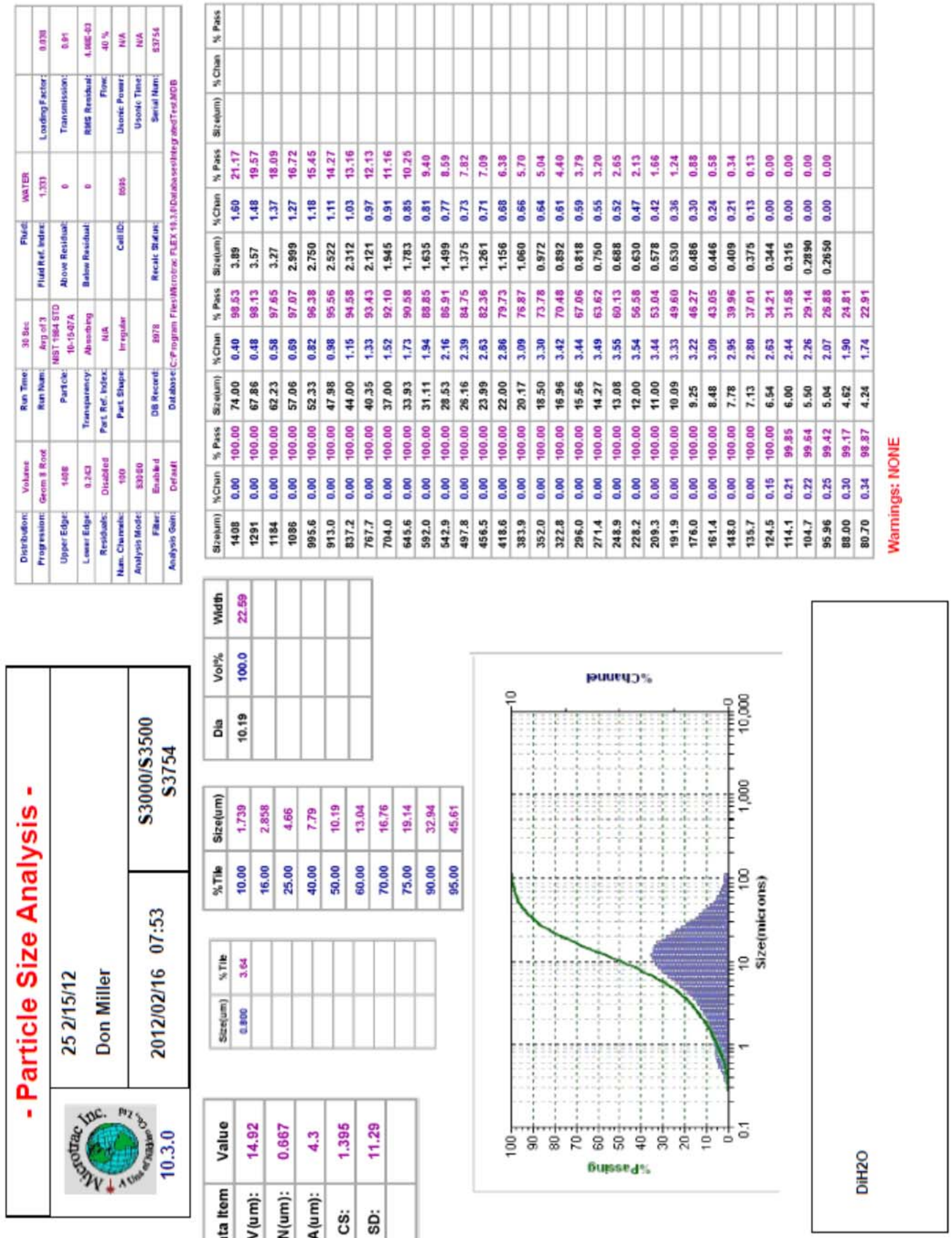

Figure A-3. Particle Size Analysis of Solids After 25 Micron Filter 

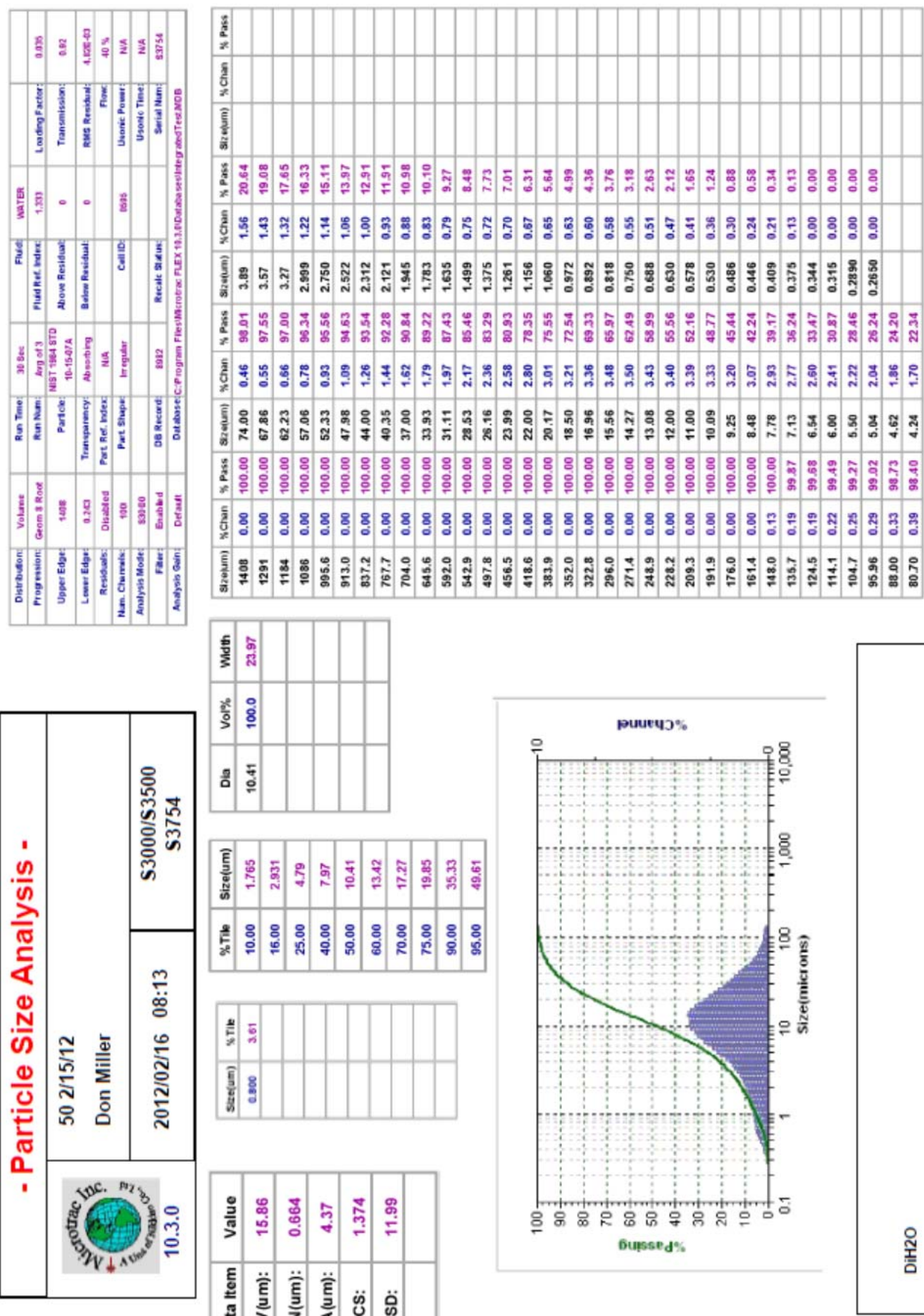

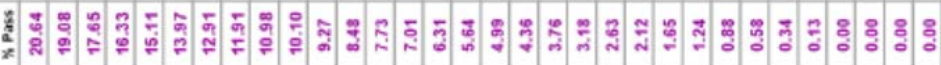

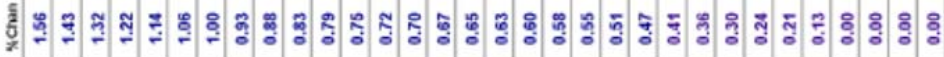

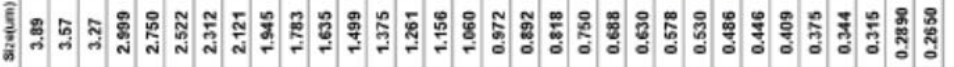

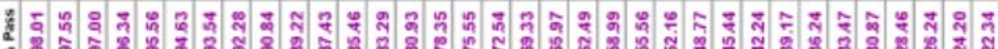

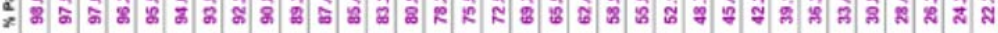

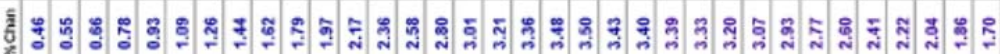

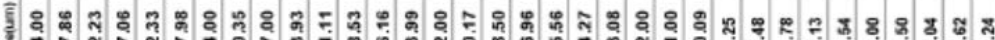

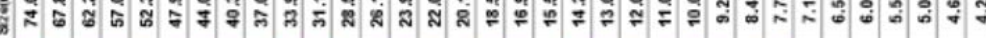

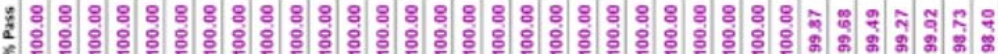

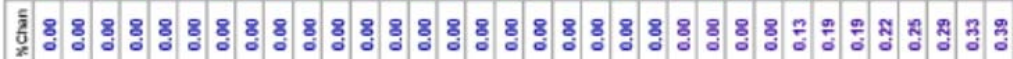

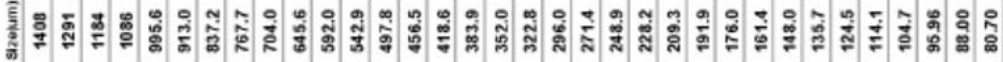
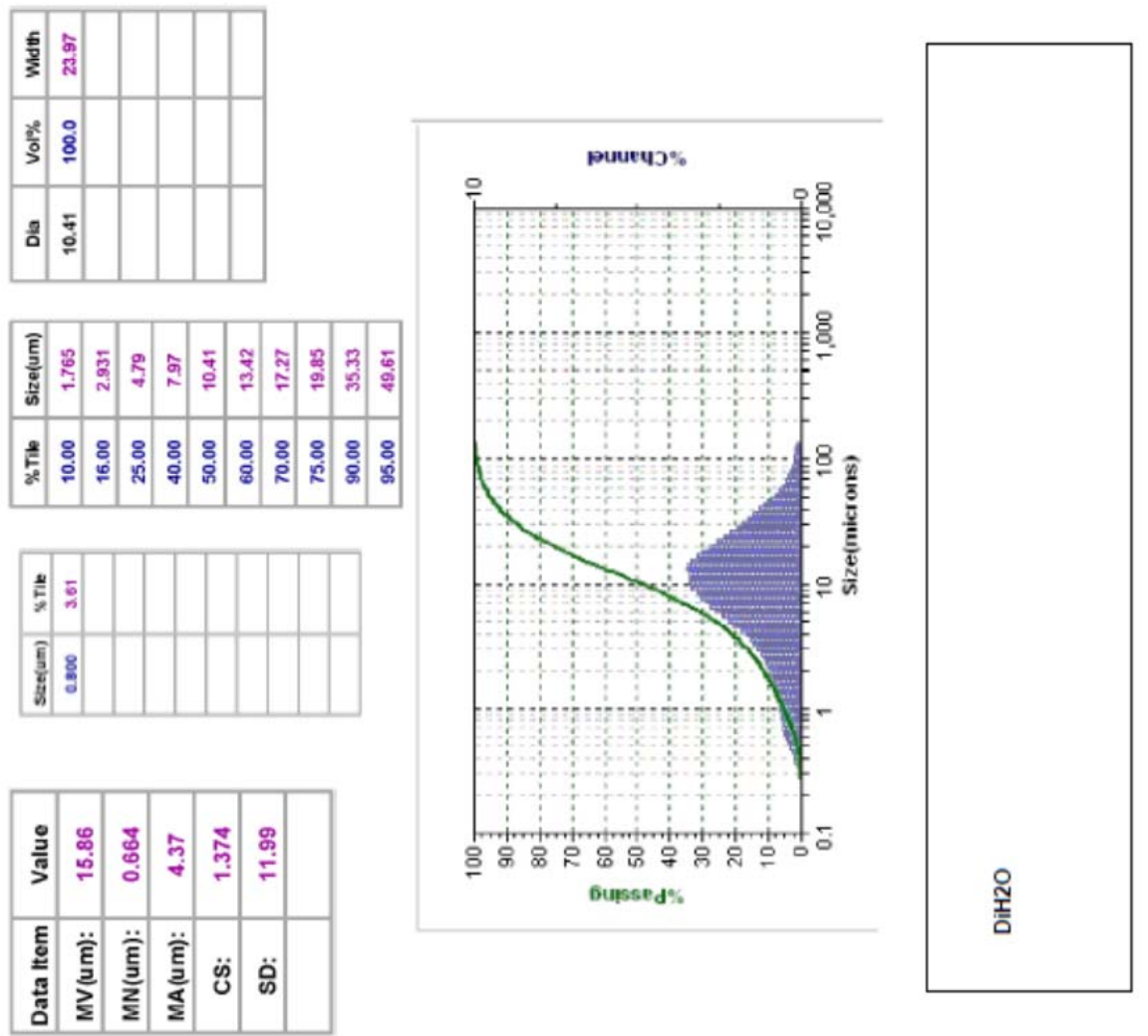

Figure A-4. Particle Size Analysis of Solids After 50 Micron Filter 

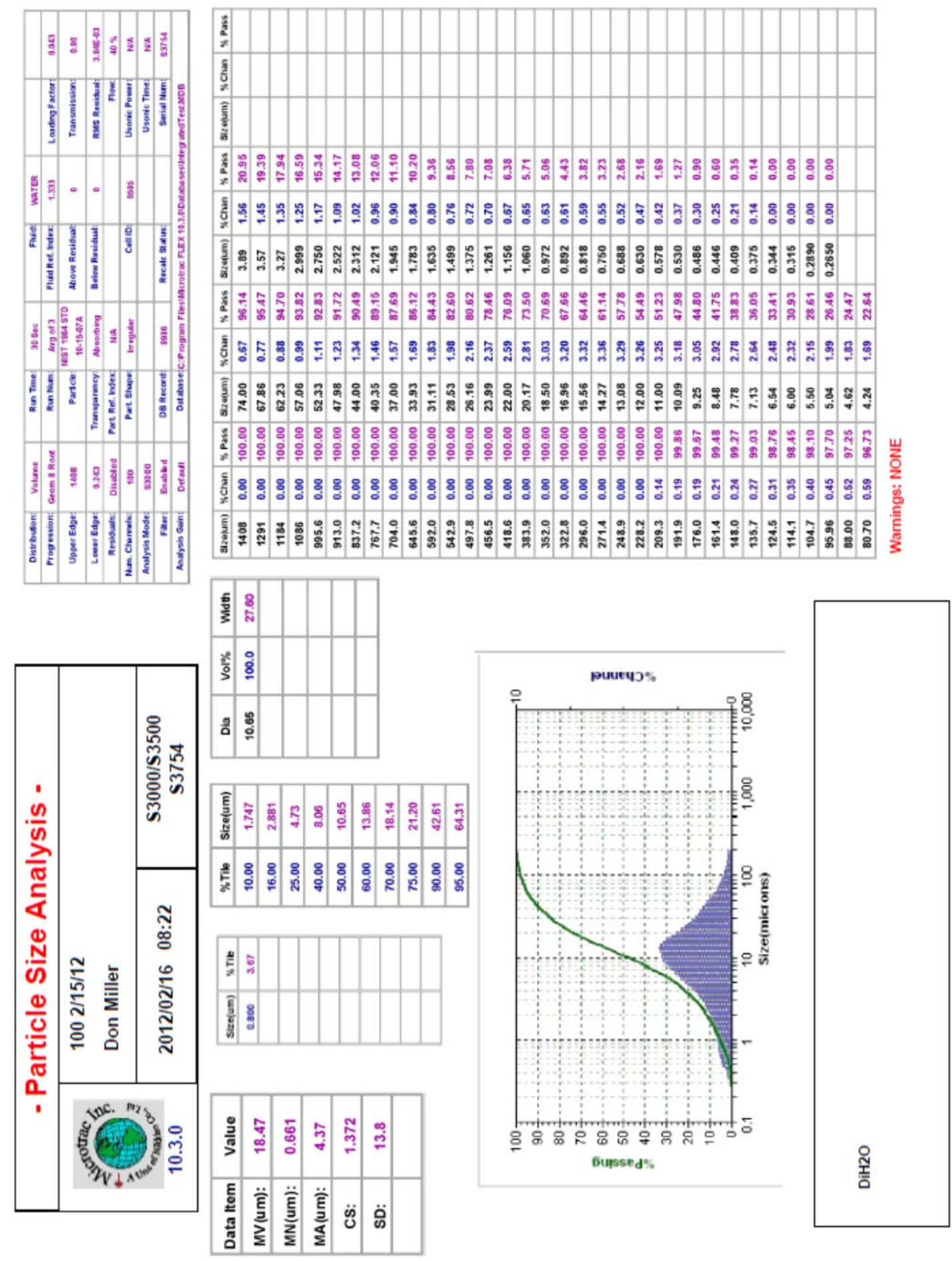

Figure A-5. Particle Size Analysis of Solids After 100 Micron Filter 